\title{
Dosilia (Porifera, Demospongiae) redefined
}

\author{
Jairo Luís Cândido ${ }^{1}$, Cecília Volkmer-Ribeiro² \& Karina Fürstenau-Oliveira²
}

1. Centro Universitário La Salle, Av. Victor Barreto, 2288, 92010-000 Canoas, RS, Brazil. (candido@unilasalle.edu.br)

2. Museu de Ciências Naturais, Fundação Zoobotânica do Rio Grande do Sul, Caixa Postal 1188, 90001-970 Porto Alegre, RS, Brazil (cvolkmer@fzb.rs.gov.br).

\begin{abstract}
Dosilia plumosa (Carter, 1849), type species of the genus, and D. brouni (Kirkpatrick, 1906), with distribution respectively in the Oriental and Ethiopic regions, are revised based on a SEM analysis of spicules, gemmules and skeletal structure. The lectotype here designated for $D$. plumosa is illustrated as well as the holotype by monotypy determined for D. brouni. Dosilia palmeri (Potts, 1885) and D. radiospiculata (Mills, 1888) distributed in the Nearctic and Neotropical regions and D. pydanieli VolkmerRibeiro, 1992, found in the Neotropical region, are revised based on a SEM analysis of spicules, gemules and skeletal structure. The holotype by monotypy is determined for D. radiospiculata. Heteromeyenia plumosa Weltner, 1895 is synonymyzed with $D$. radiospiculata. Upon the revision of its five species, the genus is redefined and a key presented.
\end{abstract}

KEYWORDS. Continental sponges, taxonomy, distribution, habitat.

RESUMO. Dosilia (Porifera, Demospongiae) redefinido. Dosilia plumosa (Carter, 1849), espécie-tipo do gênero e D. brouni (Kirkpatrick, 1906), com distribuição respectivamente nas regiões Oriental e Etiópica, são revisadas após estudos ao MEV de seus conjuntos espiculares, gêmulas e estrutura do esqueleto. São ilustrados o lectótipo selecionado para D. plumosa e o holótipo por monotipia determinado para D. brouni. Dosilia palmeri (Potts, 1885) e D. radiospiculata (Mills, 1888) com distribuição nas Regiões Neártica e Neotropical e D. pydanieli Volkmer-Ribeiro, 1992, com ocorrência na Região Neotropical são revisadas após estudos ao MEV de seus conjuntos espiculares, gêmulas e estrutura do esqueleto. Holótipo por monotipia é estabelecido para D. radiospiculata. Heteromeyenia plumosa Weltner, 1895 é sinonimizada com D. radiospiculata. A revisão das cinco espécies do gênero é concluída com a sua redefinição e apresentação de chave taxonômica.

PALAVRAS-CHAVE. Esponjas continentais, taxonomia, distribuição, hábitat.

GRAY (1867) was the first to detect and remark the occurrence of astrose microscleres ("spherical stellates", p. 550) in fresh water sponges, with the proposition of the genus Dosilia. The genus was included in the family Spongillidae erected by him in the same paper and defined upon the characteristics presented by Spongilla plumosa Carter, 1849 and Spongilla baileyi Bowerbank, 1863.

Pоттs (1887) ignored Gray's proposition and placed Spongilla plumosa and Spongilla baileyi in the genus Meyenia Carter, 1881.

Mils (1888) described Heteromeyenia radiospiculata upon material received from the United States.

TraXler (1895) identified spicules of Meyenia plumosa var. palmeri in an spongillite sample from São Paulo, Brazil.

KIRKPATRICK (1906) described Ephydatia plumosa var. brouni from Africa.

AnNANDALE (1911a) considered microscleres to be of high taxonomical importance, revalidated the genus Dosilia, indicated S. plumosa as type species, and elevated Spongilla plumosa var. palmeri Potts, 1885 and Ephydatia plumosa var. brouni Kirkpatrick, 1906 to full specific rank. The genus was thus left with three species: Dosilia plumosa (Carter, 1849), D. palmeri (Potts, 1885) and D. brouni (Kirkpatrick, 1906).

AnNANDAle (1911b) proposed Asteromeyenia to contain those freshwater sponges which, besides astrose microscleres, had two kinds of birrotulated gemmoscleres. Only two species of North American sponges were included in the new genus: Heteromeyenia radiospiculata Mills, 1888, designated type species and
Heteromeyenia plumosa Weltner, 1895. ANNADALE (1914) next placed Ephydatia plumosa var. brouni Kirkpatrick, 1906 from the Nile system in the genus Dosilia.

SCHRÖDER (1927) divided the genus Heteromeyenia Potts, 1887 into three subgenera, using the type of microsclere as the defining criteria. Thus, Heteromeyenia radiospiculata and Heteromeyenia plumosa, both of which have astrose microscleres, are grouped in the subgenus Astroheteromeyenia.

GEE (1932b) extended the distribution of the genus to the Filipines with the record of D. plumosa in River Pasig, near Manila and Pinagbuhatan Rizal, Luzon.

PENNEY \& RACEK (1968), upon validating the generic system proposed by GRAY (1867), redefined the genus Dosilia and grouped within it all the species of freshwater sponges with astrose microscleres. The genus then came to contain four species: $D$. plumosa (type species), $D$. palmeri, D. radiospiculata and D. brouni. Penney \& RACEK (1968) advanced the synonymization of Heteromeyenia plumosa in D. radiospiculata, suggesting that Weltner's species should be renamed in case it proved not to be synonymous with $D$. radiospiculata.

Boury-Esnault (1980) upon what seems to have been a mistaken reading of ARNDT (1936) wrongly extended the distribution of $D$. brouni from the AngloEgyptian Sudan to Zaire.

VolKMER-Ribeiro \& TRAVESET (1987) designated lectotype for Dosilia palmeri and provided the first Scanning Electron Microscope (SEM) images of the spicules of the species. 
VACELET et al. (1991) extended the range of Dosilia brouni from Sudan to Kenya in the Ethiopian Region and enlarged the species description offering SEM images of gemmules and gemmoscleres, besides offering precise data on the species habitat and a review of the bibliography considering its dispersion routes and present distribution in eastern Africa.

VOLKMER-RIBEIRo (1992) registered the first report of Dosilia for South America. She compared the spicules of sponges living in an small temporary lake on the Island of Maracá, Uraricoera river, northern Brazil, with those found in spongillite samples from Porto Ferreira, São Paulo, southern Brazil and upon SEM studies described a new species, Dosilia pydanieli VolkmerRibeiro, 1992 containing in its synonymy M. plumosa var. palmeri Traxler, 1895.

CÂNDIDo et al. (2000) detected variations in the microscleres of $D$. pydanieli from Lake Caracaranã, Roraima, Brazil. Actual specimens were compared to spicules found in the lake sediments dated from $4770 \mathrm{BP}$ to the present. The species had its description enlarged and the microsclere variations observed were considered indicative of some particular environmental changes.

MANCONI \& PRONZATO (2002), missed the description of $D$. pydanieli, briefly diagnosed the genus upon primarily the skeletal structure of $D$. plumosa, D. palmeri, $D$. radiospiculata and $D$. brouni. The same authors (Manconi \& Pronzato, 2005) wrongly registered $D$. brouni for Venezuela and in 2009 (MANCONI \& PRONZATO, 2009) offered no data other then those already presented by VACELET et al. (1991) for the species.

A redescription of the genus and its five species, its redefinition and corresponding taxonomic key is offered in this paper. This comprehensive study brought about a series of new evidences. First of all the constancy of the presence and large variation in the form and size of the astrose microscleres and gemmoscleres. Next the updating of the genus geographical range, pointing to a probable past gondwanic distribution. This last one allied to the need for considering continental drift as a basic clue in the understanding the distribution and evolution of freshwater sponge faunas (VOLKMER-RIBEIRO, 2007).

\section{MATERIAL AND METHODS}

The specimens studied were catalogued and deposited in the Porifera collection of the Museu de Ciências Naturais, Fundação Zoobotânica do Rio Grande do Sul, Porto Alegre, Brazil (MCN- POR) or loaned from the following institutions: BMNH, British Museum of Natural History, London, England; ZMB, Museum für Naturkunde der Humboldt-Universität, Berlin, Germany; USNM, National Museum of Natural History, Washington, D.C., USA (Gee collection); INPA, Instituto Nacional de Pesquisas da Amazônia, Manaus, Brazil. The preparation of the spicular material for Transmitted Light Microscopy (TLM) and Camera Lucida Drawing (CLD) followed VOLKMER-RIBEIRO \& RÜTZLER (1997), and Scanning Electron Microscopy (SEM), VolKMER-Ribeiro \& TurCQ (1996). SEM was performed at MCN. Fifty measures were obtained for each kind of spicules for each one of the examined materials (Tab. I).

\section{RESULTS}

\section{Dosilia plumosa (Carter, 1849) (Figs 1-14)}

Spongilla plumosa CARTER, 1849:85; Bowerbank, 1863:449.

Dosilia plumosa; Gray, 1867:551; Annandale, 1911a:111; 1911b:593; 1912:384; 1918:1213; GEE, 1932a:28; 1932b:529; Laubenfels, 1936:37; Jewell, 1952:450; Penney, 1960:39; PenNey \& RaceK, 1968:128; Manconi \& Pronzato, 2002:934; Zubair et al., 2006:237.

Meyenia plumosa; CARTER, 1881:84; PotTs, 1887:233.

Ephydatia plumosa; WeLtner, 1895:126.

Type material. Lectotype, INDIA, Mumbai: Gemmules of the lectotype BMNH 1863:7:25:8 (BMNH) (Ezquizolectotype MCN-POR 5377) (Fig. 1), H. J. Carter col. (examined). Paralectotype, INDIA, Mumbai: Gemmulliferous fragment of one paralectotype USNM 39298 (Gist Gee Collection, USNM) (Ezquizoparalectotype MCN-POR 1518), H. J. Carter col. (examined).

CARTER (1849) refers to three or four studied specimens of the syntypic series deposited in the British Museum, the specimen BMNH 1863:7:25:8, with abundant gemmules (Fig.1), was the one which detained the largest

Table I. Measures in $\mu \mathrm{m}$ of the spicules of Dosilia palmeri (Potts, 1885), D. radiospiculata (Mills, 1888), D. pydanieli Volkmer-Ribeiro, 1992, D. plumosa (Carter, 1849) and D. brouni (Kirkpatrick, 1906) (Min, minimum; Max, maximum; Ave, average).

\begin{tabular}{|c|c|c|c|c|c|c|c|c|c|c|c|c|c|c|c|c|}
\hline \multirow[b]{2}{*}{ Spicules } & & \multicolumn{3}{|c|}{ D. palmeri } & \multicolumn{3}{|c|}{ D. radiospiculata } & \multicolumn{3}{|c|}{ D. pydanieli } & \multicolumn{3}{|c|}{ D. plumosa } & \multicolumn{3}{|c|}{ D. brouni } \\
\hline & & Min & Max & $\overline{\text { Ave }}$ & Min & $\operatorname{Max}$ & Ave & Min & Max & Ave & Min & $\operatorname{Max}$ & Ave & Min & Max & Ave \\
\hline $\begin{array}{l}\text { Aster } \\
\text { microscleres }\end{array}$ & Diameter & 28.1 & 78.4 & 41.6 & 23.0 & 51.1 & 36.1 & 26.8 & 64.7 & 42.4 & 23.3 & 56.2 & 35.5 & 27.4 & 52.1 & 38.6 \\
\hline Oxea & Length & 54.5 & 134.2 & 86.5 & 39.2 & 128.3 & 68.5 & 37.5 & 95.2 & 57.8 & 46.6 & 112.3 & 67.9 & 49.0 & 170.7 & 98.0 \\
\hline microscleres & Width & 3.1 & 8.7 & 5.8 & 2.5 & 10.9 & 5.0 & 1.9 & 6.1 & 3.4 & 2.7 & 7.6 & 4.7 & 3.1 & 9.0 & 5.7 \\
\hline \multirow[t]{2}{*}{ Megascleres } & Length & 341.5 & 491.4 & 433.6 & 333.0 & 1093.0 & 586.7 & 303.4 & 649.0 & 468.5 & 401.1 & 600.5 & 514.3 & 353.3 & 640.3 & 491.1 \\
\hline & Width & 11.8 & 20.4 & 16.3 & 8.9 & 47.8 & 21.0 & 6.7 & 31.8 & 17.0 & 11.8 & 27.8 & 20.6 & 13.3 & 32.9 & 24.8 \\
\hline \multirow[t]{3}{*}{ Gemmoscleres } & Rotules & 31.5 & 41.7 & 36.7 & 26.1 & 57.5 & 40.1 & 22.5 & 37.0 & 30.8 & 22.3 & 33.8 & 26.8 & 24.2 & 39.2 & 30.9 \\
\hline & Length & 64.5 & 121.5 & 103.1 & 61.2 & 365.2 & 143.5 & 83.1 & 144.3 & 110.4 & 68.6 & 110.0 & 92.8 & 65.7 & 93.1 & 78.1 \\
\hline & Width & 5.8 & 9.1 & 7.3 & 3.5 & 13.9 & 8.9 & 2.9 & 6.4 & 4.8 & 3.3 & 6.3 & 5.0 & 3.5 & 6.2 & 4.9 \\
\hline Gemmules & Diameter & 660.0 & 809.0 & 734.5 & 516.0 & 718.0 & 617.0 & 590.0 & 843.0 & 716.5 & 622.0 & 749.0 & 685.5 & 484.0 & 580.0 & 532.0 \\
\hline
\end{tabular}


number of characteristics of the species, for which reason it is here designed as lectotype.

Type locality: according to CARTER (1849) the sponge was found fixed to the walls of two (not nominated) freshwater tanks in the island of Bombay (now Mumbai), India. However, today only the Banganga tank with its clear waters persists as a ground for worshipping as well as tourism events. The tanks were built in the $14^{\text {th }}$ century to supply the population with drinking water at the dry period.

Material examined. PAQUISTAN, Kashmir: Jhelum River at Muzaffarabad, BMNH - 1879:12:26:33 (MCN-POR, 1570), Schlaginwelt col.

Diagnosis. Sponges with small astrose microscleres with numerous micro-rotulated rays, rarely attaining the condition of oxeas with some smaller rays at the middle part of the spicule; megascleres long, smooth, gradually pointed oxea; gemmoscleres delicate, uniform amphidiscs, with straight, cylindrical, thin shafts sparsely spined up to the base of the rotules; rotules umbonate, border of rotules thick from light to deeply cut into an irregular number of teeth or hooks, all turned towards the shaft.

Description. Sponges extremely delicate, hemispherical, with a convex surface, having light protrusions and depressions or slight undulations; skeleton anistropic, plumo-reticulated, consisting mostly of fine radial primary fibres that branch towards the sponge surface, radial fibers linked together by rare secondary pauci- or monospicular fibres and spongin septa (Fig. 8); spongin scarce; ectosome not conspicuous; gemmules abundant, free, ovoid, reaching the surface, though more abundant at the base of the sponge (Fig. 1); dry sponge brittle, yellowish; when living, these sponges are light brown or bright green (ANNANDALE, 1911b).
Megascleres: fusiform, long, straight, smooth oxea, gradually tapering at the extremities (Fig. 2).

Microscleres: astrose, small, with numerous short smooth or sparsely spined rays radially projecting from a central nodule and capped by an irregular arrangement of small curved spines (Figs 2-4); through the enlargement of two opposite rays, the astrose microsclere attains the condition of an spiny microxea, an irregular number of smaller rays remaining yet at the spicule centrum (Fig. 5), all of them bearing micro-rotulated extremities. The spines along the central spicule are curved towards the central region of the spicule.

Gemmoscleres: slender straight amphidiscs, with little variation in form and size; shafts cylindrical, sparsely spined throughout their length; shaft spines with irregular sizes, straight, conical, sharply pointed; rotules large, uniform in size and shape, from umbonate to almost flat, with edges lightly to deeply and irregularly indented and curved towards the shaft; teeth or rays at the rotule margin microspined (Figs 2, 6, 7, 11, 14).

Gemmules: ovoid, free, well developed, dense pneumatic layer set on the laminated internal gemmular membrane; air spaces in the pneumatic layer small and regular; gemmoscleres radially embedded in the pneumatic layer, the outer rotules slightly extending beyond this layer but covered by the outer gemmular membrane; foraminal tube conical, wider at the base, crossing the pneumatic layer and the outer gemmular membrane and slightly projecting beyond the external surface, closed at the base and the summit with spongin seals (Figs 8, 9, 12-14).

Distribution. From Kashmir, Paquistan to Mumbai and Madras, India, and Southeast Phillipines.

Habitat. The sponges thrive in tanks and rain-water storage pools, attaching themselves to the walls or to

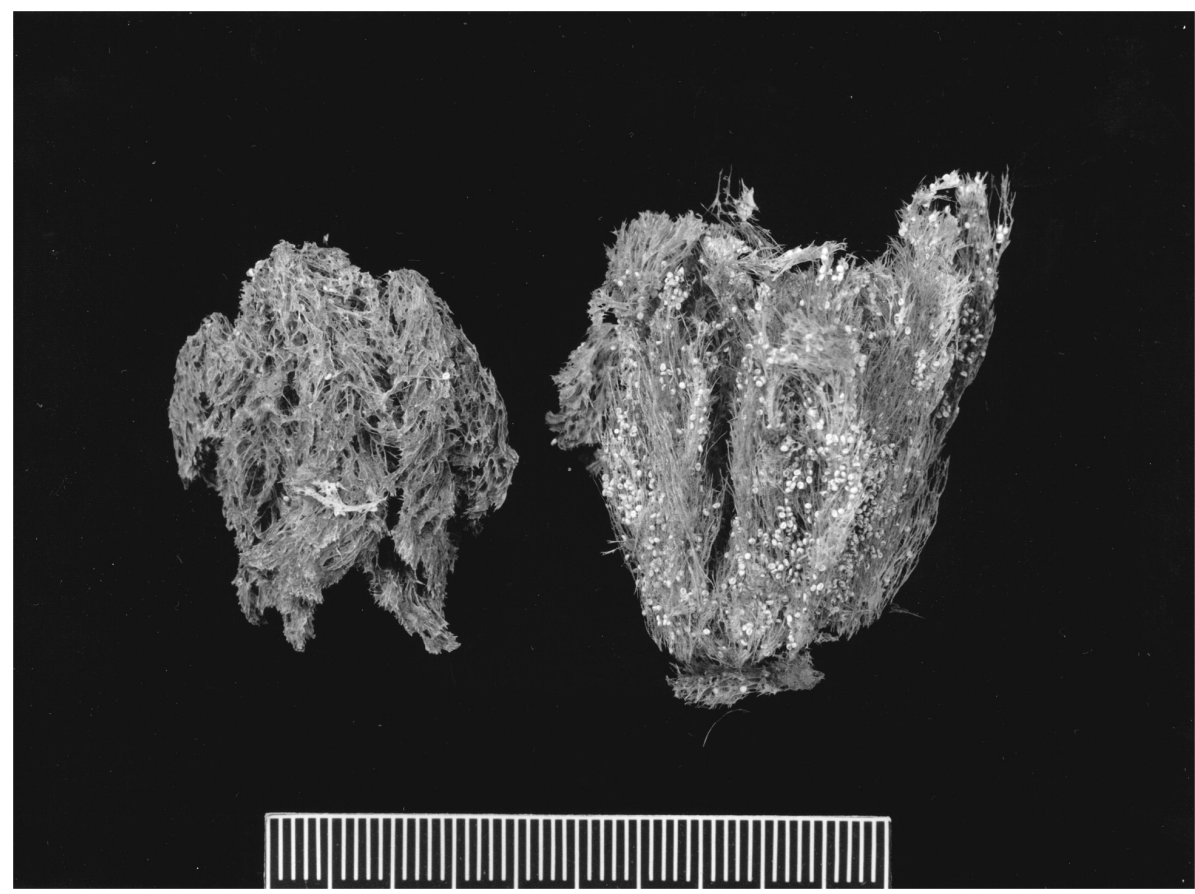

Figure 1. Dosilia plumosa (Carter, 1849). Upper and bottom view of lectotype (BMNH 1863:7:25:8) (scale in millimetres). 

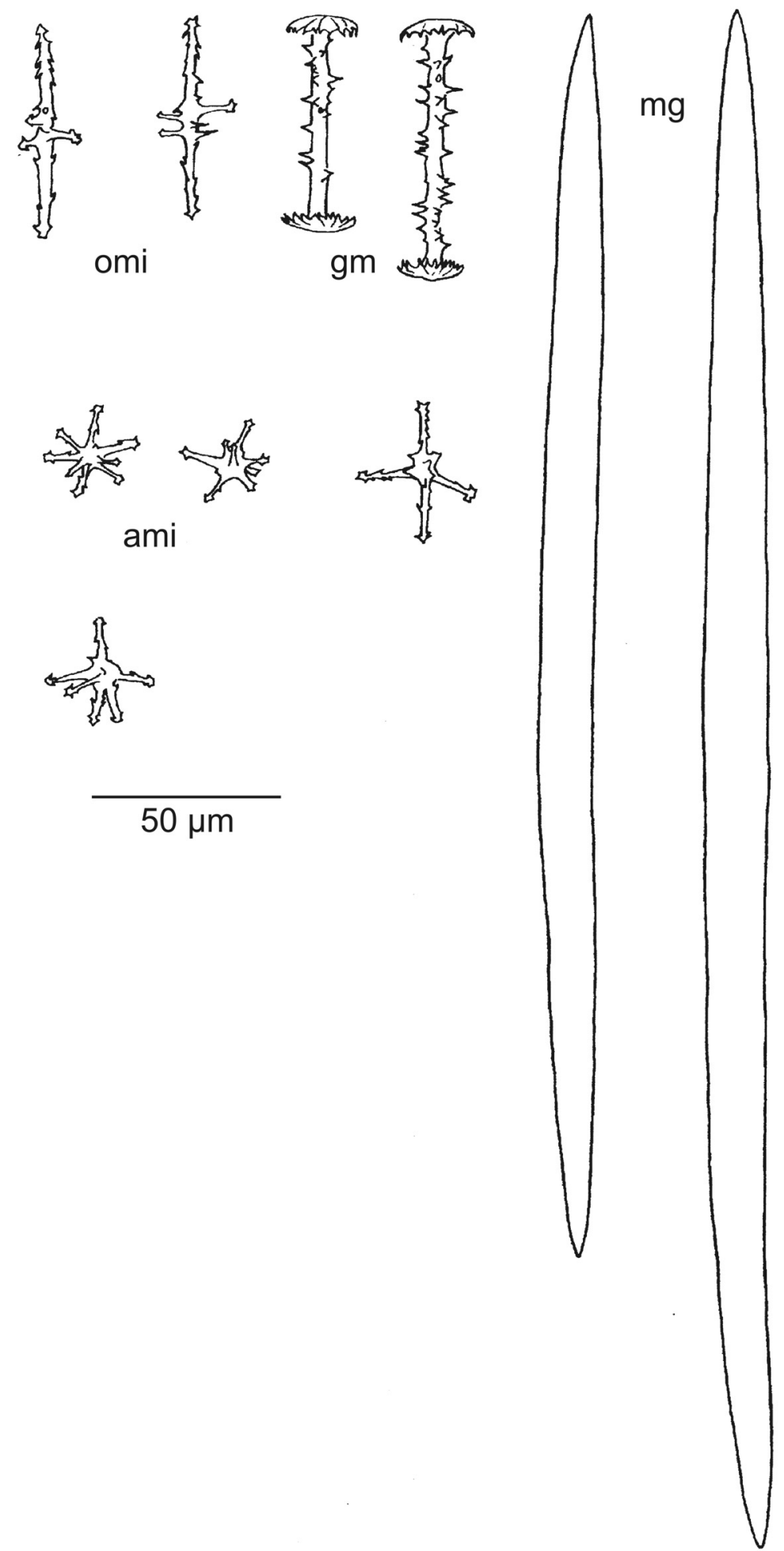

Figure 2. Dosilia plumosa (Carter, 1849), spicules: megascleres (mg), gemmoscleres (gm), astrose microscleres (ami) and oxea microscleres (omi).

the stems of aquatic plants, in tropical or temperate regions where they are subject to the seasonal rains, remaining part of the year submerged and part emerged, when they dry and the gemmules guarantee survival until the next rainy season.

Remarks. Originally described by CARTER (1849) from Bombay, the species had its distribution extended to
Southeast India by ANNANDALE (1911a), while collecting and identifying specimens of $D$. plumosa in Madras, which were, according to the author, "attached to the stems of the water lilies that grew in pools of slightly saline water". The material collected by Schlaginwelt and deposited in the British Museum with the number BMNH 1879:7:2:1, probably identified by Carter as $D$. plumosa, had not, until 

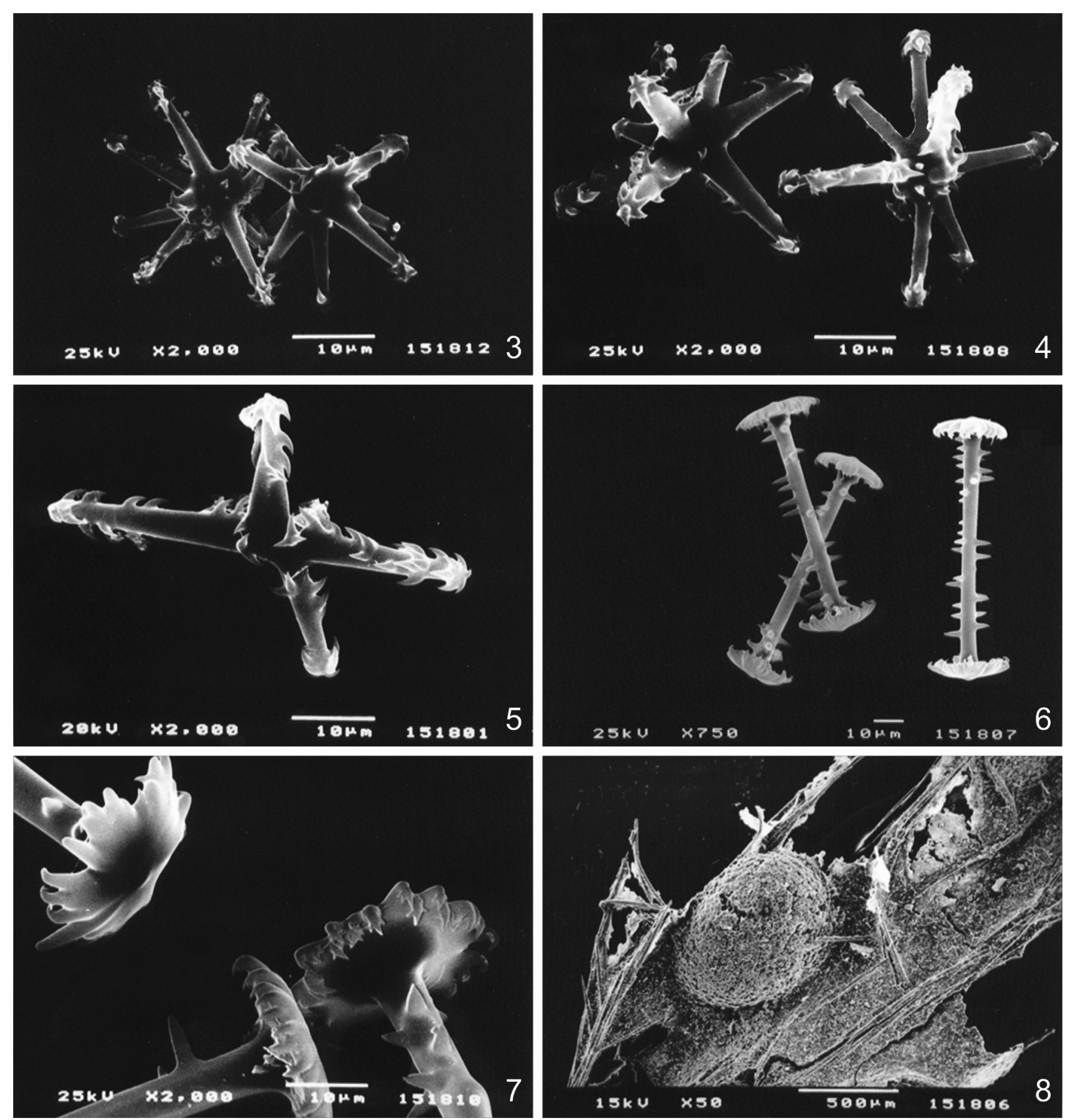

Figures 3-8. Dosilia plumosa (Carter, 1849): 3, 4, astrose microscleres with the rays capped by microrotules; 5, astrose microsclere with reduced number of rays; 6 , gemmoscleres; 7 , irregularly cut border of gemmosclere rotules with incurved microspines; 8 , the very thin main skeleton fibers and gemmule.

then, been referred to in the bibliography. With this record and that of ZuBAIR et al. (2006) the distribution of $D$. plumosa in the Oriental Region extends north from Kashmir, in Pakistan to south, in the Philippines (GEE, 1932a), incorporating the entire territory of India. PENNEY \& RACEK (1968) described astrose microscleres with eight to twelve rays, usually smooth and with a small number of curved spines at the extremities; in the studied material astrose microscleres with up to six smooth or sparsely spined rays were observed, their spines curved towards the central region of the spicule. The same authors as well as AnNANDAle (1911a) described two types of microscleres: astrose and anfioxea; however it was noted the presence in one same specimen of intermediary microscleres, clearly showing a gradation between the two previously described types of microscleres.

\section{Dosilia palmeri (Potts, 1885)}

(Figs 15-25)

Meyenia plumosa var. palmeri Pоттs, 1885:587, pl. VI, figs a-g; 1887:234, pl. X, fig. VI; Kellicott, 1891:103.

Dosilia palmeri; Annandale, 1911a:111; Smith, 1921:17; Gee, 1932a:28; ARndt, 1933:19; Rioja, 1940:174, 187; Eshleman, 1950:40; Penney, 1960:39; Penney \& Racek, 1968:129; Harrison, 1974:41; Poirrier, 1982:59; Volkmer-Ribeiro \& Traveset, 1987:235; Frost, 1991:114, 116; Manconi \& Pronzato, 2002:934 

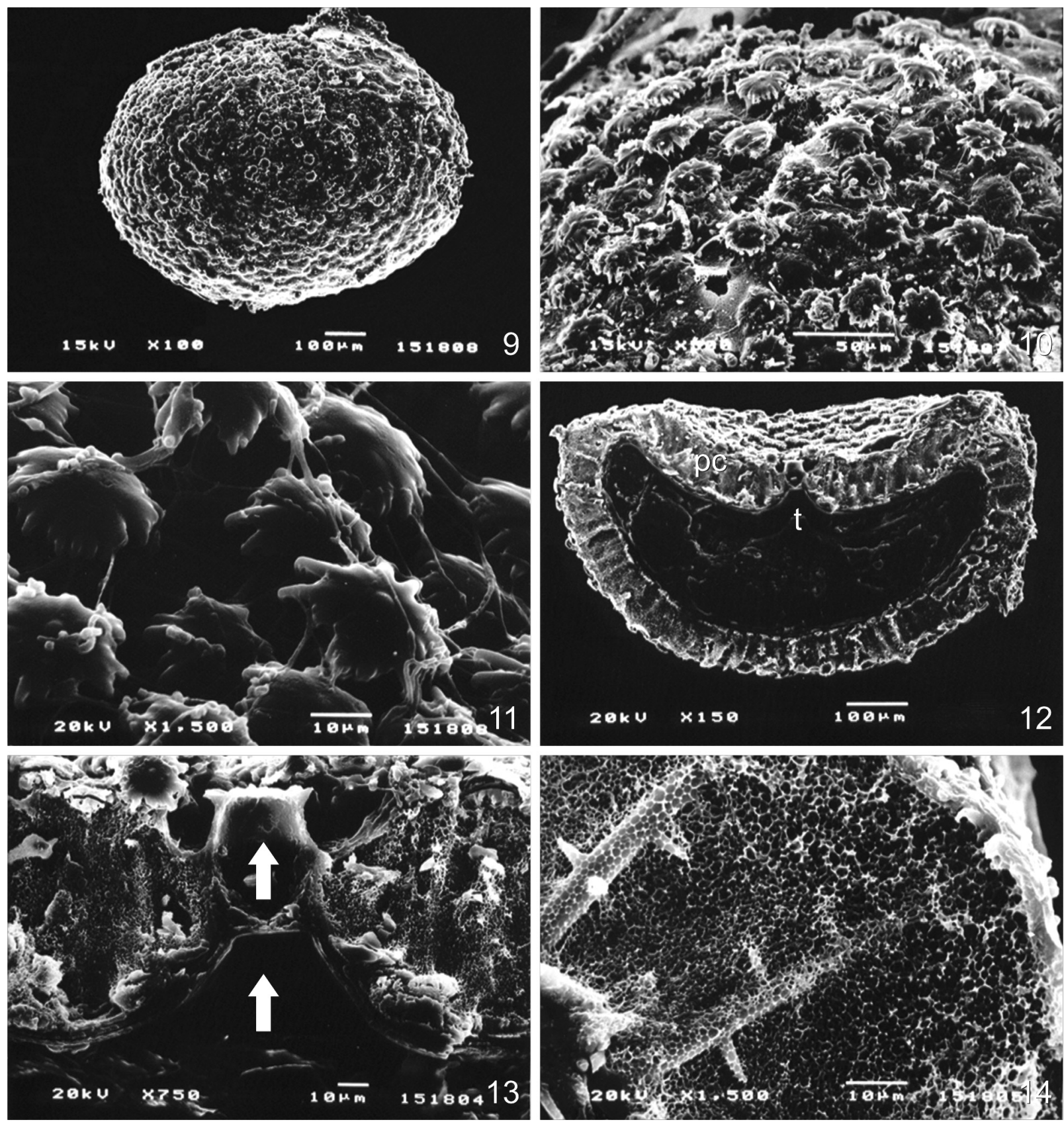

Figures 9-14. Dosilia plumosa (Carter, 1849), details of gemmular structure: 9, gemmule; 10, 11, gemmular surface with rotules of gemmoscleres and initial formation of the outer coat; 12, cross section of gemmule exhibiting the pneumatic coat (pc), the foraminal tube $(\mathrm{t})$ and the radial setting of the gemmoscleres; 13, detail of the inner and outer laminae (arrows) of the foraminal tube and the inner gemmular coat; 14, cross section of the pneumatic coat with two embedded gemmoscleres.

Type material. Lectotype. MEXICO, Sonora: Lerdo (Banks of the Colorado river, near Lerdo), V.21.1885, E. Palmer col. [USNM 5419- deposited in the BMNH (MCNPOR: 2324 Ezquizolectotype)] (examined) (VoLKMERRibeiro \& Traveset, 1987, fig. 9); paralectotype, same data of lectotype [USNM 34055 (MCN-POR: 1265, Ezquizoparalectotype)] (examined).

Type locality: seasonally flooded banks of the Colorado river near Lerdo, Sonora, México, at the time an wild region near Fort Yuma, were Dr. Palmer exercised his physician expertise towards the US Army.

Diagnosis. Sponges with astrose microscleres of various sizes, with a stout centrum and irregularly sized rays grading to micro-oxeas, with some large rays retained at the spicule centrum, sclere rays or shafts capped by microrotules; megascleres long, straight, abruptly pointed, micro-spined oxea, except at the extremities; amphidiscs stout with great variation in size though not in shape, shafts thick, straight, the largest having spines concentrated in the middle portion, the smallest densely spined, except at the base of the rotules; rotules expanded, umbonate, with thin borders, lightly to deeply indented, the teeth turned towards the spicule shaft.

Description. Dry sponges brown, fragile and brittle, subspherical (VOLKMER-RIBEIRO \& TRAVESET, 1987, fig. 9) reaching $15 \mathrm{~cm}$ in diameter; surface hispid due to 


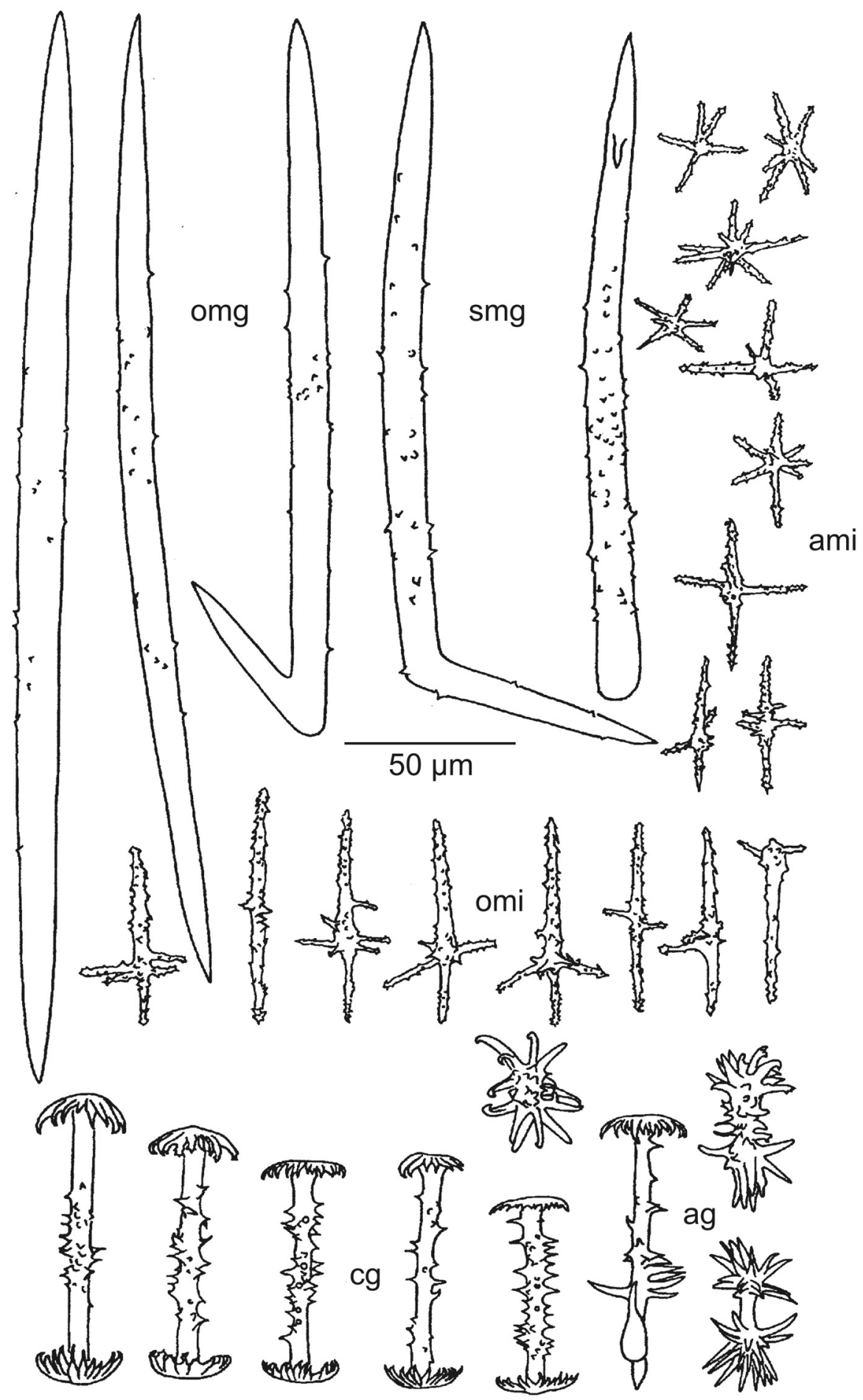

Figure 15. Dosilia palmeri (Potts, 1885), spicules: oxea megascleres (omg), style megascleres (smg), common gemmoscleres (cg), atypical gemmoscleres (ag), series of the microscleres with the reduction of rays from astrose (ami) taking to oxea (omi).

projections of the main radial fibers and crossed by furrows containing the oscular apertures; pinacoderm conspicuous; skeleton reticulated, anisotropic, main fibres radial, paucispicular, secondary fibers generally unispicular, ectosome absent; gemmules abundant, distributed from the base to the surface of the sponge (Figs 16-18); EshLEMAN (1950) reports the sponge forming large spreading green colonies.

Megascleres: long, straight or slightly curved, spiny, gradually very sharp pointed oxeas, some styles present, with spines concentrated in the central region of the spicule; rare oxea with one extremity turned into angles varying between $150^{\circ}$ and $45^{\circ}$ (Figs $15,17,18$ ).

Microscleres: robust astrose microscleres with five to ten irregularly sized rays protruding from a widened centrum, evolving, from the enlargening of two opposite rays, into microxeas which retain the centrum, from where a variable number of very irregular rays project, or yet 
sparsely spined microxea, with a single large ray projecting from a widened centrum, extremities of rays and shafts capped by microrotules (Figs 15, 21).

Gemmoscleres: robust amphidiscs with little variation in shape and size, the longer ones less numerous, sparsely spined or spines occasionally grouped in the middle portion of the shaft: rotules expanded, from umbonate to almost flat, their borders regularly incised in an irregular number of hooks or teeth, from slightly to sharply curved towards the shaft and with microspined extremities; variations may be found with shafts very short or almost absent, smooth or densely spined and terminated by an irregular, dense cluster of hooks and spines of varied sizes and degrees of curvature (Figs 15, 18-20, 22, 23, 25)

Gemmules: free, hemispherical or subspherical, inner gemmular membrane foliated, pneumatic layer thick, with minute regular air cameras; gemmoscleres radially embedded up to the outer rotule in the thick pneumatic layer, the outer rotule of the longer gemmoscleres protruding beyond this layer; foraminal tube wider at the base, double sealed and contained inside the gemmular layer (Figs 22-25).

Distribution. From Colorado river, Sonora, northwestern Mexico to Williston, Levy County, Florida, USA.
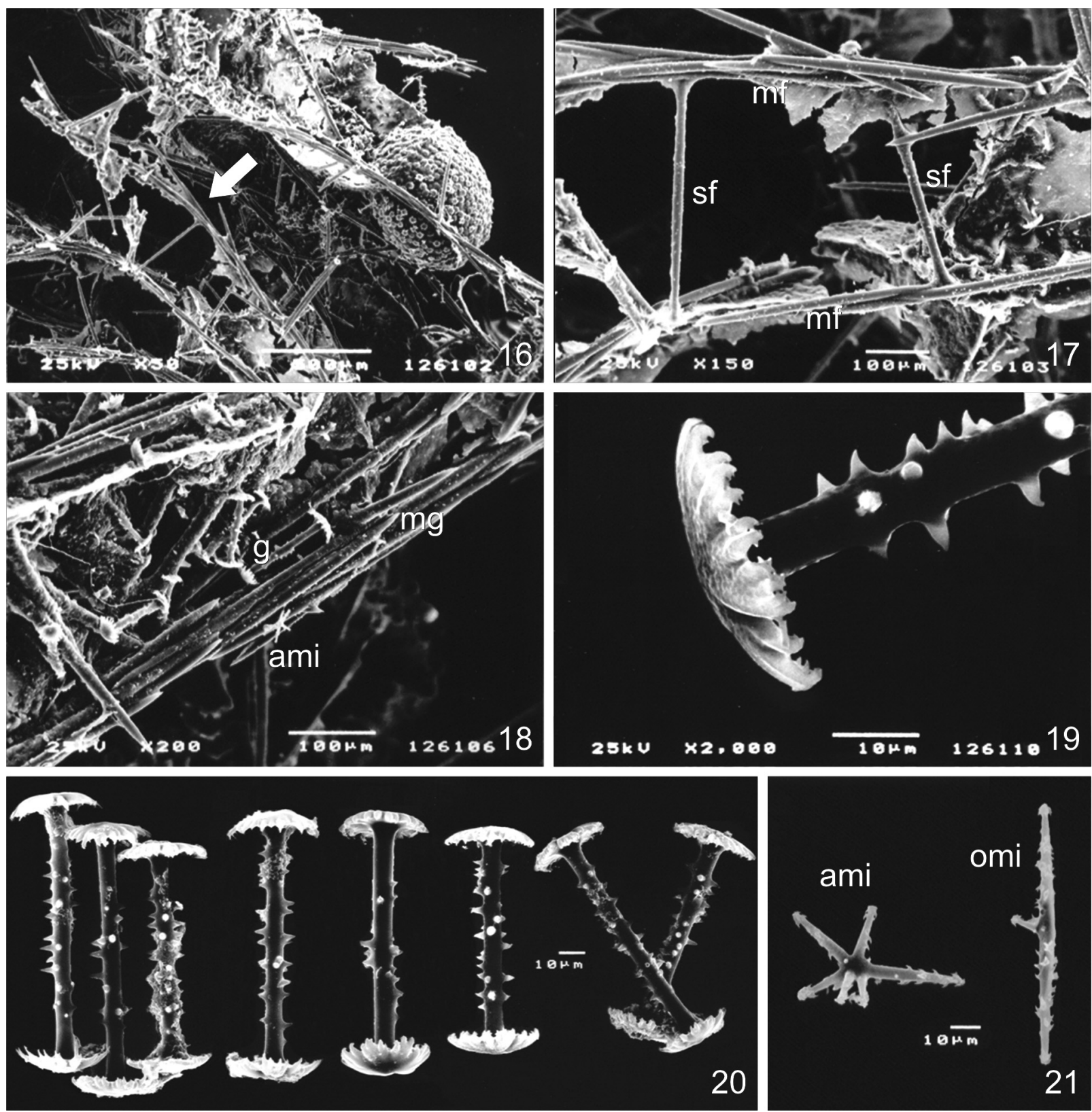

Figures 16-21. Dosilia palmeri (Potts, 1885): 16, skeletal structure with the thin main and secondary fibers, gemmule loosely set at the surface of the sponge close to a group of several gemmoscleres where a new gemmule will form; 17, enlargement of the area indicated by arrow at (A), with two main fibers (mf) linked by two secondary monospicular fibers (sf); 18, spicular categories of $D$. palmeri: megascleres $(\mathrm{mg})$, gemmoscleres $(\mathrm{g})$ and astroses microscleres (ami); 19, gemmosclere rotule with the microspines at the extremities of the incurved teeth; 20, variations of the size and spine covering of the gemmoscleres; 21 , astrose microsclere with sparsely spined irregular rays (ami) and astrose microsclere reduced to an oxea with one single middle ray arising from the original centrum (omi). 

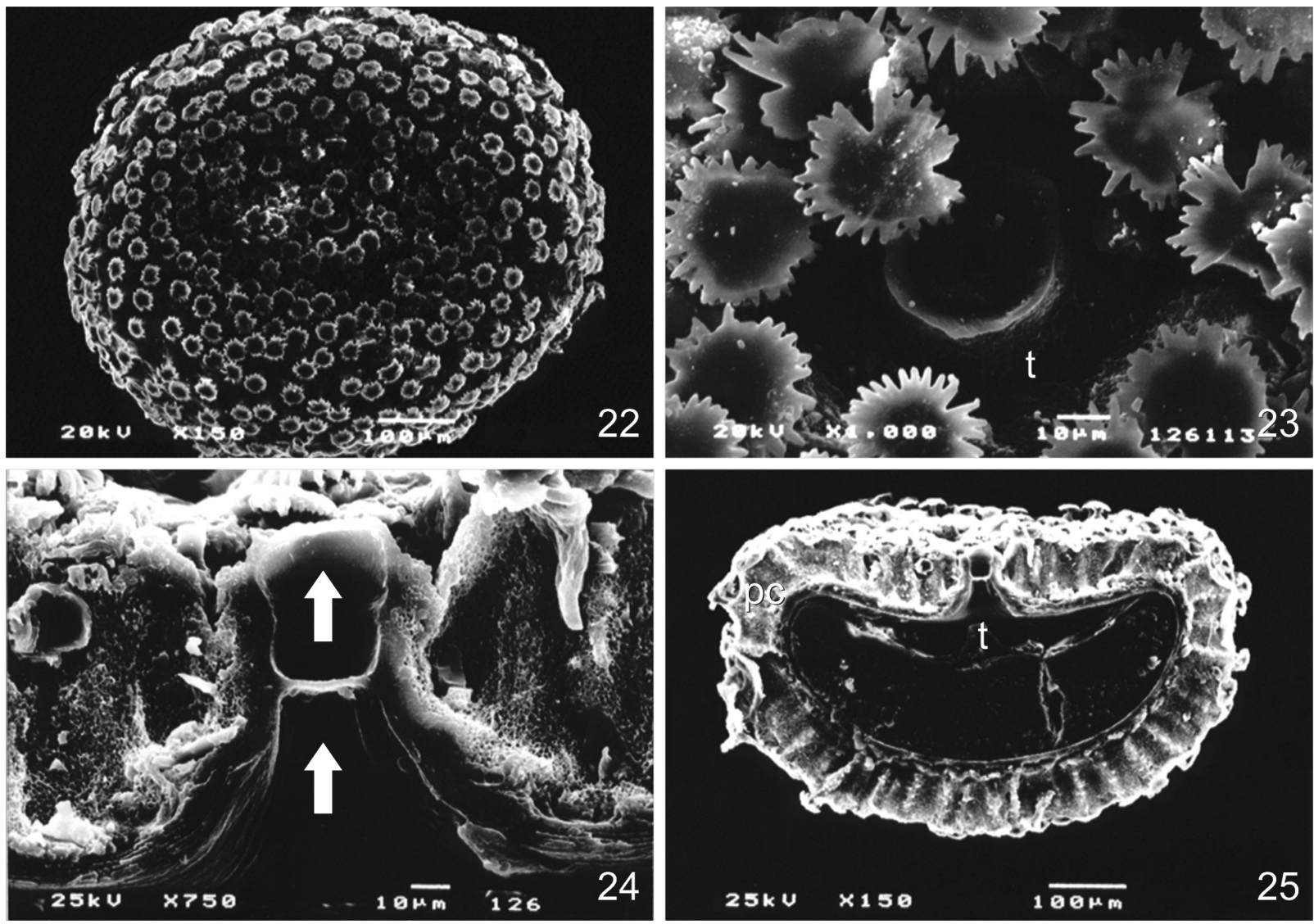

Figures 22-25. Dosilia palmeri (Potts, 1885), gemmulles: 22, gemmular surface with the foraminal tube at central position; 23, protruding rotules of the gemmoscleres with their indented profile and top of the foraminal tube (t); 24 , details of the upper and lower septae of the foraminal tube (arrows), of the thick laminated inner coat and the small and regular air spaces of the pneumatic coat; 25 , transverse section of one gemmule showing: the short foraminal tube (t) and the thick pneumatic coat (pc) with radial embedding of the gemmoscleres, the longer ones are seen to be few in number.

Habitat. Temporarily flooded areas (two months a year) along the banks of the Colorado river (Sonora County, Mexico) with dry climate, hot and arid, and vegetation consisting of mesquit, cactus and screw-bean (Strombocarpa pubescens, Fabaceae). The sponges encrusted the branches of $S$. pubescens, reached by the flooding waters, taking the form of wasp nests in the dry season, or sponges forming large spreading green colonies in a sink-hole in Florida (EshLEMAN, 1950).

Remarks. PenNeY \& RACEK (1968) suggest Central America as probable distribution of $D$. palmeri. According to PotTs (1885) and Eshleman (1950), specimens were collected in the northwestern Mexico and Florida, respectively, what does not correspond to Central America, but to North America. PenNey \& RaCeK's (1968) hypothesized geographical distribution was assumed by Frost (1991) and MANConi \& PRONZATO (2002), with no evidence so far offered from sampled specimens.

\section{Dosilia radiospiculata (Mills, 1888)} (Figs 27-37)

Heteromeyenia radiospiculata Mills, 1888:313; Weltner, 1895:128; Kellicott, 1897:50; GeE, 1932a:34; Rioja, 1940:185. Heteromeyenia plumosa Weltner, 1895:127; ANNANDAle, 1909:405;

Gee, 1931:46; 1932a:33; Penney \& Racek, 1968:132, 133.

Asteromeyenia radiospiculata; AnNandale, 1911b:593; Sмith,
1921:17; Old, 1936:11; WuRTZ, 1950:5; Jewell, 1952:453; Penney, 1960:33

Asteromeyenia plumosa; AnNANDALE, 1911b:593; SMith, 1921:17; Old, 1936:13; Eshleman, 1950:42; Rioja, 1953:431; Penney, 1960:33.

Astromeyenia radiospiculata; SCHRÖDER, 1927:101.

Astromeyenia plumosa; SCHRÖDER,1927:101.

Dosilia radiospiculata; PenNey \& RACEK, 1968:131; PoIRrIer, 1972a:455, 458; 1972b:434; HaRrison, 1974:41; Frost, 1991:117 SowKA, 1999:211.

Dosilia heterogena Penney \& RACEK, 1968:133 nomen novum for Heteromeyenia plumosa Weltner, 1895; POIRRIER, 1972b:434 1982:59

Type material of $D$. radiospiculata. Holotype, USA, Ohio: Cincinnati, Ohio river, 12 miles above Cincinnati, IX.1887, G. B. Twitchell col. [BMNH 1890:1:9:300], Ezquizoholotype (MCN-POR: 2324, a few gemmulles from the holotype) (examined). Type material of Heteromeyenia plumosa (fragments with gemmulles - Texas, donation by E. Potts) XII.16.1890 [ZMB 1477] (MCN-POR:8350 fragment)].

MiLls (1888) based the description of this species on a single specimen, a gemmuliferous fragment with dimensions $7.5 \mathrm{~cm} \times 6 \mathrm{~cm} \times 5 \mathrm{~cm}$ thick. The specimen is deposited in the British Museum, reason why an holotype by monotypy is now determined for the species.

Type locality: Ohio river, twelve miles from Cincinnati, Ohio, USA. 


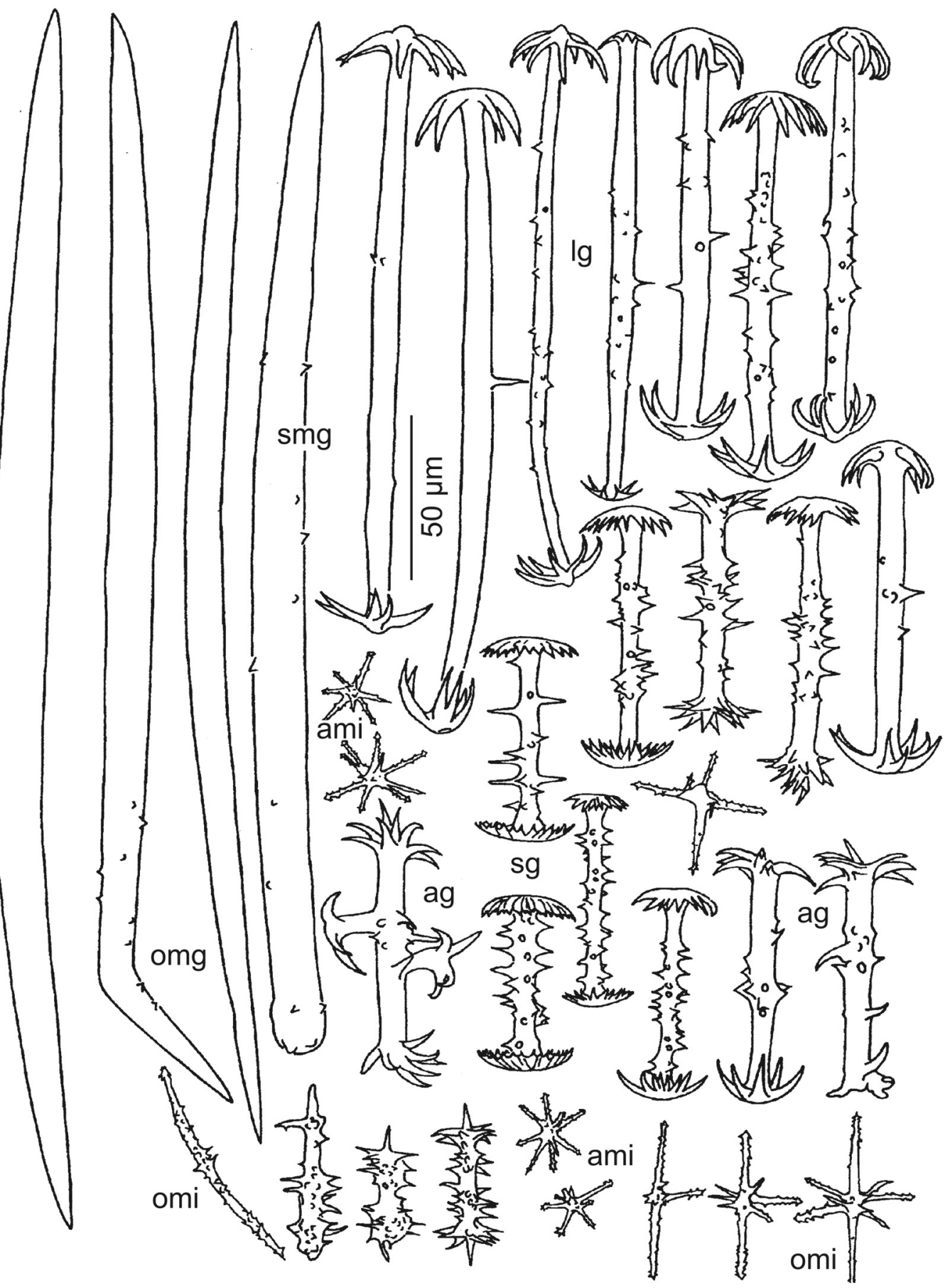

Figure 26. Dosilia radiospiculata (Mills, 1888), spicules: oxea megascleres (omg); style megascleres (smg); long gemmoscleres (lg); short gemmoscleres (sg); atypical gemmoscleres (ag); astroses microscleres (ami); oxeas microscleres (omi).

Material examined. USA, Texas: Grande river, unknown colector [USNM 39392 (fragments with gemmulles - MCN-POR: 1517)]. Louisiana: New Orleans (N. Gist Gee, collection, unknown colector) (USNM 53037).

Diagnosis. Sponges with abundant small astrose microscleres with rays extremely varied in size and number, all capped by micro-rotules, evolving, from the enlargening of two opposite rays, into microxeas with a widened centrum from which some fewer rays yet protrude; megascleres stout, gradually sharp pointed, straight or slightly curved, smooth or sparsely spined oxea, styles may be present; gemmoscleres, robust amphidiscs with remarkable variation of size and shape, shafts thick , straight to slightly curved, the largest ones gradually tapering towards the rotules, smooth or with spines concentrated in the central region and with conspicuously umbonate rotules formed by robust hooks turned towards the shaft, the smallest with densely spined shafts, rotules expanded, slightly umbonate, incised into a large number of teeth with extremities 
also turned towards the shaft. Atypical gemmoscleres are also observed, with thicker shafts and a median concentration of disorganized rays or spines and rotules consisting of sets of disorganized hooks or yet extremely short spiny shafts with no discernible rotules.

Description. Sponges subspherical with compact texture, the surface marked by nodules and furrows; oscules large and irregularly distributed; skeleton a dense anisotropic reticulum with paucispicular primary fibres, secondary fibres monospicular, organic bounding scarce; basal skeleton with a confused distribution of fibers; ectosome a conspicuous tangentially disposed layer of
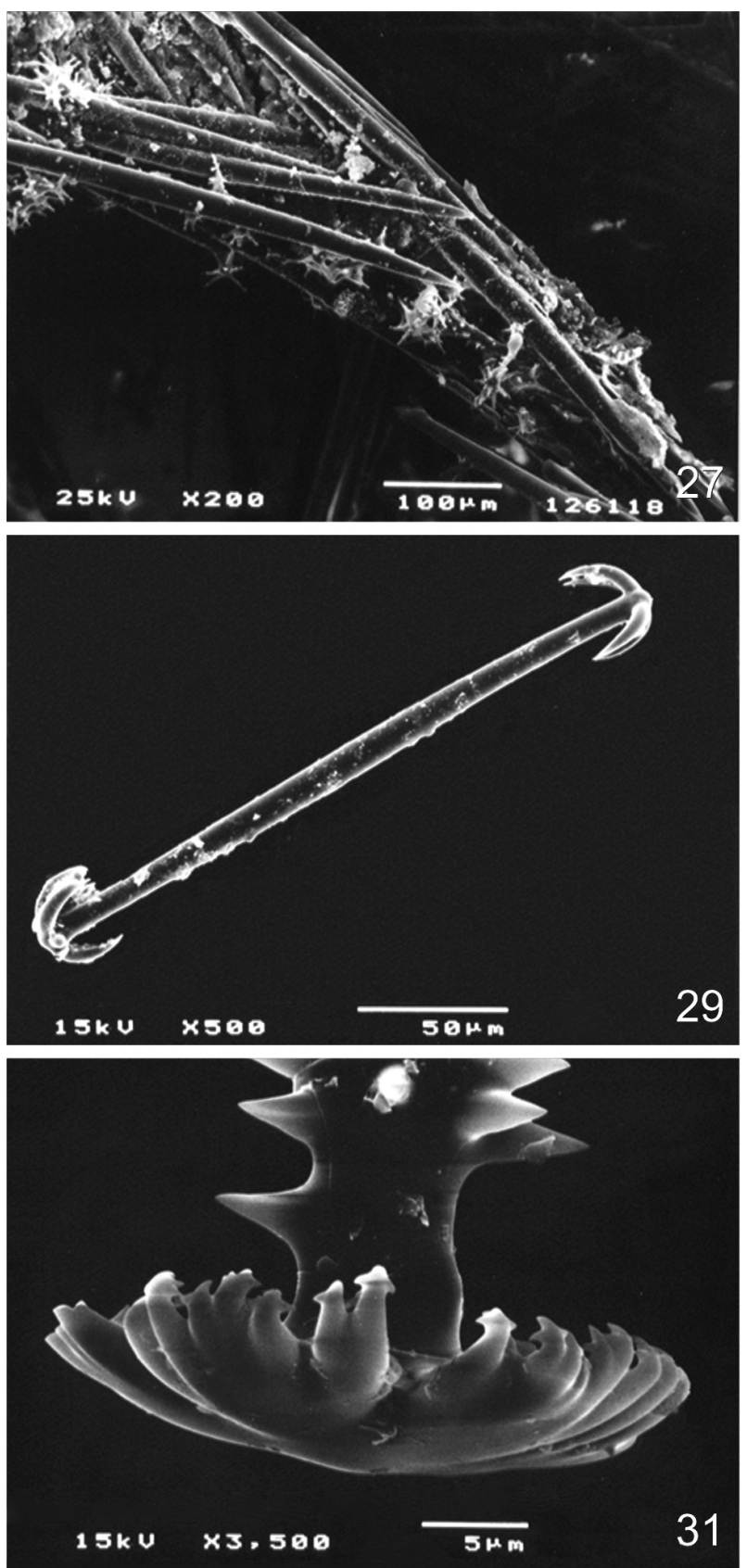

megascleres and microscleres; gemmulles forming a compact mass at the sponge base however abundant and free up to the surface; dry sponge grey but darker in the upper portion of the skeleton, consistency fragile and brittle (Figs 27, 28).

Megascleres: straight or slightly curved, rarely spined oxeas with gradually tapering extremities; some styles present (Figs 26-28).

Microscleres: astrose microscleres particularly abundant in the ectosome and in the vicinity of the gemmulles, consisting of six to eight smooth or spiny rays of irregular size projecting radially from a centrum
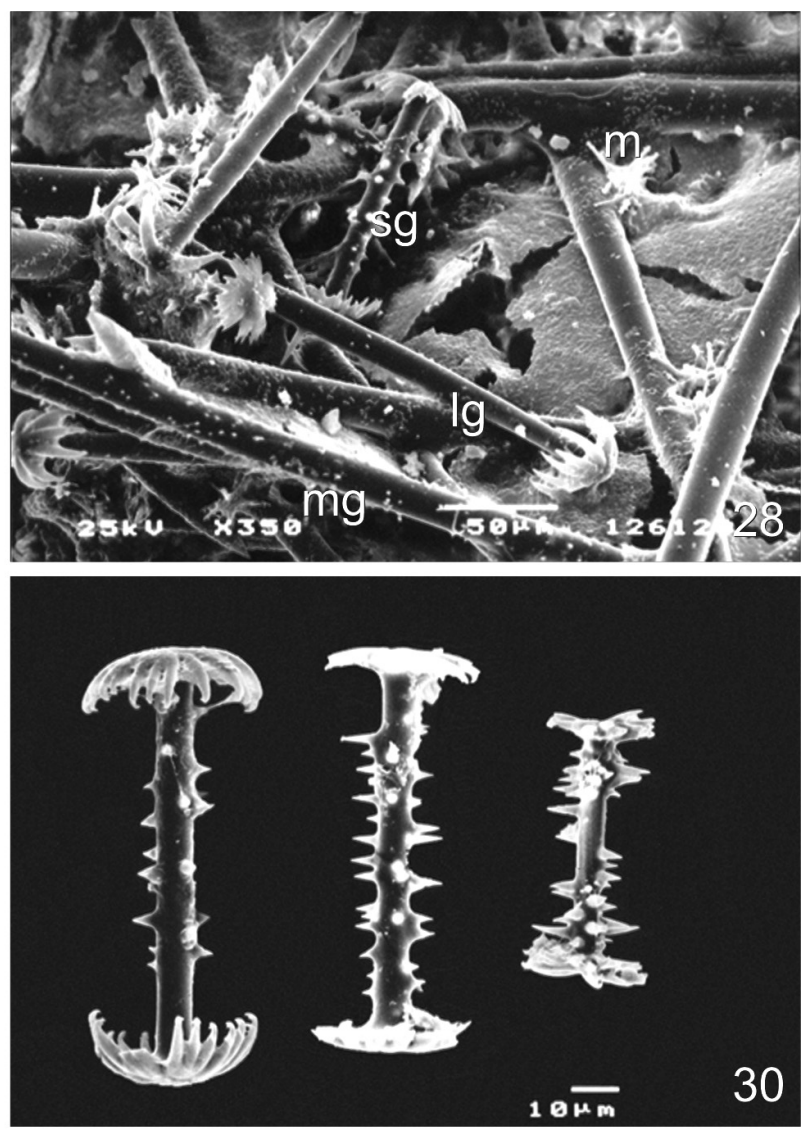

Figures 27-32. Dosilia radiospiculata (Mills, 1888): 27, detail of the sponge ectoderm with abundant astrose microscleres randomly distributed; 28, dry surface of specimen showing the pinacoderm, spines on the megascleres (mg) long gemmosclere with smooth shaft and short gemmoscleres ( $\lg$ and $\mathrm{sg}$ ); 29, long gemmosclere with minute sparse spines on the shaft and the incurved hooks which form the rotules; 30 , set of shorter gemmoscleres showing the variation of the spine covering on the shafts, of the curvature and size of the rotules as well that of their borders; 31, detail of the marginal teeth of the rotules with their microspine termination; 32, presence, in the gemmoscleres in formation, of six orifices at the base of the indentation of the rotules, vestiges of the protein filaments of the gemmoscleres. 
and capped by micro-rotules; a transition from astrose to anfioxea occurs with the size increase of usually two opposite rays, the centrum remaining with the projection of a few smaller rays, the micro-rotules at the rays extremities reduced in size as the rays are reduced in number (Figs 26, 27, 33, 36).

Gemmoscleres: amphidiscs that grade from (1) very long spicules, barely abundant, though present in all the gemmulles observed, shafts straight or slightly curved, smooth or with sparse spines concentrated in the middle region of the spicule, the amount and length of the shaft spines inversely proportional to the length of the same: rotules conspicuously umbonate, consisting of a circle of stout hooks, strongly bent towards the shaft, the curvature of the hooks increasing proportionally to the length of the spicule; to (2) abundant amphidiscs, rotules slightly umbonated and equal, their diameter $1 / 3$ to $1 / 2$ of the length and the border irregularly incised into numerous coalescent smaller hooks or teeth, their extremities generally trifurcated, shafts spiny, cylindrical (Figs 26, 28-32). Between these two categories, a number of intermediary forms, with shafts more densely covered by spines, particularly in the central region, with umbonated rotules formed from a greater number of curved back hooks more or less laterally fused. Atypical gemmoscleres occur, the rotules a sheaf of hooks, straight or slightly curved towards the shaft: shafts short, thick, densely spined, the spines of varying sizes, or shafts almost smooth, though with two to four middle stout expansions (Fig. 26). At the base of broken spines near the edge of rotules in formation six orifices may be seen at SEM analysis, pointing to the location of the protein filaments that served as the base for the depositing of silica during the spicule formation (Fig. 32). Loose gemmoscleres in the skeleton in places where the gemmulles will form (Fig. 28).

Gemmulles: abundant, spherical or subspherical, free; inner gemmular layer three laminated, pneumatic layer thick with minute air spaces the longer gemmoscleres, approximately 20 per gemmule, pierce the pneumatic layer with around $1 / 3$ of the axis projecting beyond the external gemmular membrane: the short gemmoscleres also radially embedded in the pneumatic

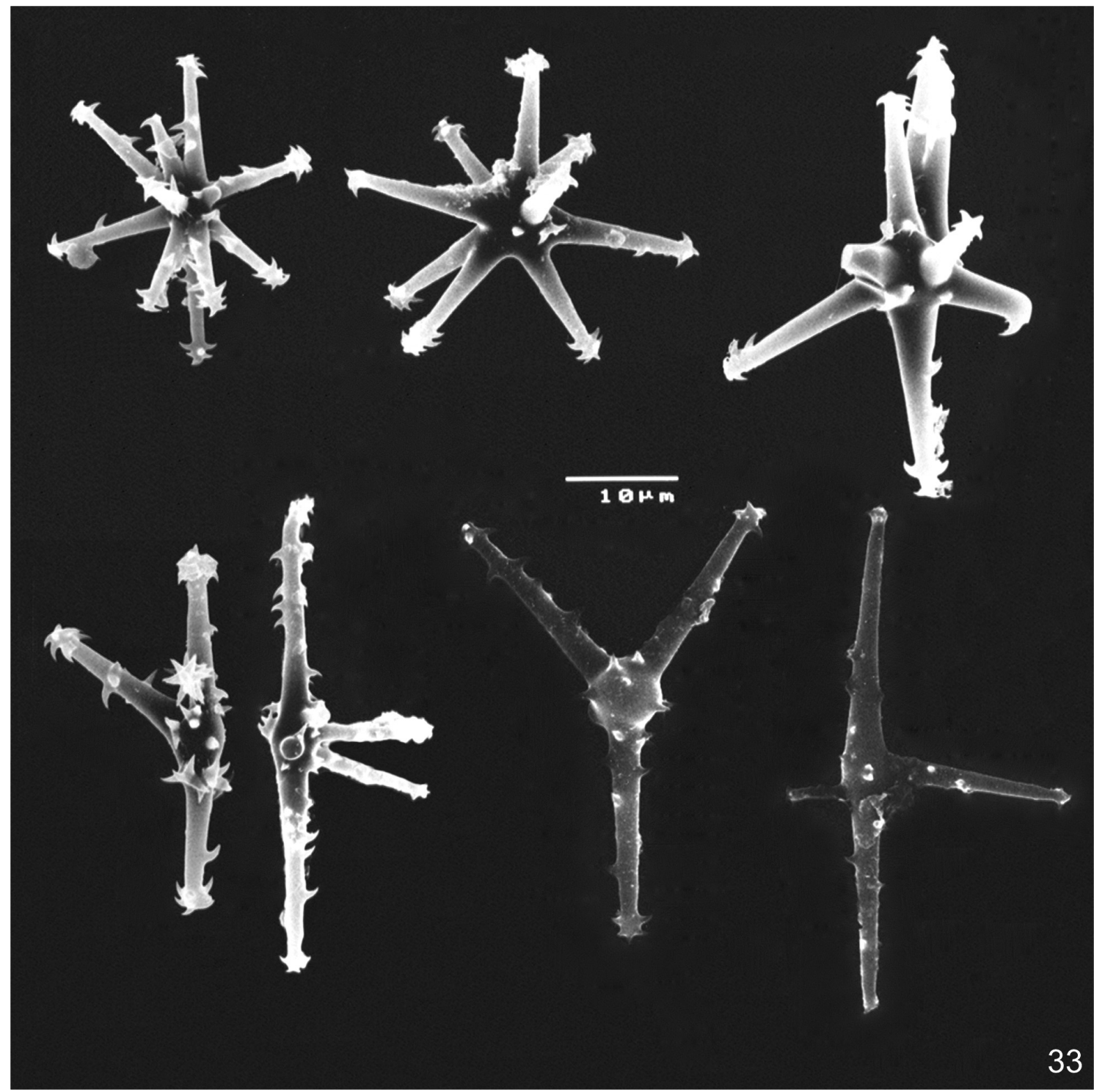

Figure 33. Astrose to oxea microscleres in Dosilia radiospiculata (Mills, 1888) (2000 x). 
layer, the upper rotule projecting above it, though covered by the conspicuous outer gemmular membrane; foraminal tube cylindrical, double sealed and not projecting above the pneumatic layer (Figs 34-37).

Distribution. North to South of USA from the Canadian border to Florida, Arizona and California to center of Mexico.

Habitat. Rivers and water reservoirs in subtropical and temperate regions subjected to seasonal variations of the water level. The sponge encrusts the macrophytic vegetation or the walls of water reservoirs.

Remarks. Mills (1888) as well as PENNEY \& RACEK (1968) described the gemmoscleres as subdivided into two classes, conspicuously distinct in shape and size. From the measurements taken and observations made with TLM and SEM, it is concluded that, in truth, there is a gradation, in both shape and size, between these two distinct extremes of gemmoscleres. Despite the lesser abundance of long gemmoscleres, all the mature gemmulles present in the examined material had the two extreme forms of gemmoscleres, long and short, as well as intermediary forms, as described above. Long gemmoscleres, therefore, cannot be considered uncommon, or not constant as stated by PENNEY \& RACEK (1968).

According to Mills (1888), D. radiospiculata has two distinct microscleres, one astrose and the other anfioxea, each with distinct characteristics. The present observation of intermediary microscleres, between asters and anfioxeas refutes Mills' description and demonstrates a gradation between these two forms, beginning from the aster that, with the enlargening of two opposite rays, gives rise to the anfioxea with a reduced number of smaller rays at the original centrum. MiLls (1888) described the aster as hexaradiated and PENNEY \& RACEK (1968) reported to "spicules with 6 to 8 rays originating from a central nodule..."; yet, using SEM analysis, it was possible to reveal asters with up to 10 rays.

The analysis of the type material of Heteromeyenia plumosa Weltner, 1895 (ZMB 1477) permitted the detection of the similarity, in size and shape, of the spicular components, with those of Dosilia radiospiculata (Mills, 1888), fully conforming to the description of the latter. The area of distribution is also the same. With this it is possible to definitively exclude the proposal of a nomen novum Dosilia heterogena put forward by PENNEY \& RACEK, 1968 for Heteromeyenia plumosa of Weltner, placing it as a synonym of Dosilia radiospiculata.

Heteromeyenia longistylis Mills, 1884 has gemmoscleres, megascleres and spiny oxea microscleres (VOLKMER-Ribeiro \& TrAVESET, 1987; fig. 5) that fully correspond to the description of $D$. radiospiculata,
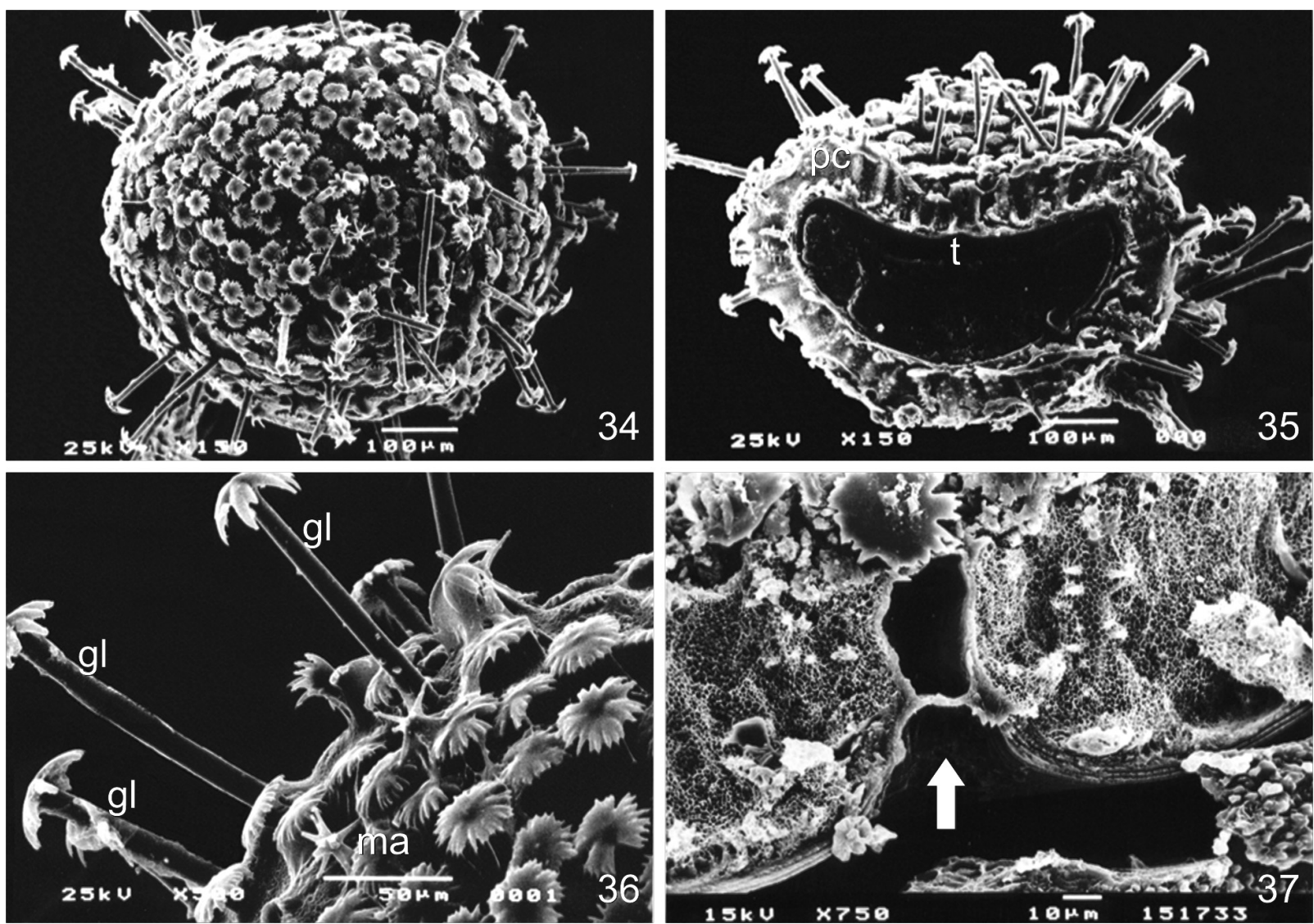

Figures 34-37. Dosilia radiospiculata (Mills, 1888), gemmulles: 34, gemmular surface with several longer gemmoscleres projecting their rotules high above the pneumatic coat with the shorter ones; 35 , cross section showing the foraminal tube (t) and the thick pneumatic coat $(\mathrm{pc})$ with the embedding of the shorter gemmoscleres; 36, detail of the gemmule surface evidencing one smooth and two spiny shafts of three longer gemmoscleres (gl), as well as the thin outer coat, and the differences presented by the rotules of the long and the short gemmoscleres; 37, detail of the pneumatic coat showing its minute and regular air cameras, the foraminal tube with its double sealing and the three laminated inner gemmular coat. 
lacking only the astrose microscleres characteristic of Dosilia. The only material of $H$. longistylis is the slide that constitutes the designated holotype and illustrated in Volkmer-Ribeiro \& Traveset (1987). This slide, deposited in the collection of E. Potts (Philadelphia Academy of Natural Sciences), produced on a very small sample with very few gemmulles, permits the hypothesis that the sponge had not yet formed asters. A study of samples collected throughout the area of distribution of the $D$. radiospiculata and Heteromeyenia longistylis may show that both are in reality the same species, what would take Dosilia radiospiculata (MILls, 1888) to the condition of junior synonym of $H$. longistylis (Mills, 1884).

Material of Asteromeyenia plumosa studied by Rioja (1953) could not be secured for comparative study. However his illustration for the specimens collected in Puebla, Mexico, show astrose microscleres besides the conspicuous differences in size and shape of the gemmoscleres characteristic of $D$. radiospiculata.

\section{Dosilia brouni (Kirkpatrick, 1906) (Figs 38-55)}

Ephydatia plumosa var. brouni KIRKPATRICK, 1906:226; WeltnER, 1913:476.

Dosilia brouini; Annandale, 1911a:111.

Dosilia brounii; Annandale, 1914:245; Penney, 1960:39.

Dosilia plumosa var. brownii; GEE, 1931:34.

Dosilia brownii; GEE, 1932a:28

Dosilia brouni; ARndT, 1936:17; PenNey \& RACEK, 1968:130; BouryEsnault, 1980:209; Vacelet et al., 1991:11; Manconi \& Pronzato, 2002:934; 2009:125. (non Dosilia brouni Manconi \& Pronzato, 2005:3237)

Type material. Holotype, SUDAN, White Nile, Goz Abu Guma, 200 miles south of Khartoum, H. Broun col. (BMNH 1905:6:30:6 - deposited in the British Museum). (Ezquizolotype MCN-POR 5378, minute fragment with gemmulles) (examined).

The holotype, here established as a monotype, due to the fact that KIRKPATRICK (1906) described D. brouni from one single specimen consisting of a nodule $1.5 \mathrm{~cm}$ in diameter, which is currently deposited in the British Museum under number BMNH 1905:6:30:6 (Fig. 38) and, as such, here declared holotype by monotypy.

Type locality: White Nile, Goz Abu Guma, 200 miles south of Khartoum, Sudan.

Material examined. SUDAN, Khor Ayalia, between Blue Nile and Dinder river, H. Broun col. (BMNH 1909:7:2 - deposited in the British Museum); KENYA: S.W. shore of Lake Baringo, 1930, E. B. Worthington col. (BMNH 1932:3:15:2 - deposited in the British Museum); KENYA: gemmuliferous fragments, Lake Baringo. XII.1979. J. J. Tiercelin col. (MCN-POR 1590, 2275-2277).

Diagnosis. Sponges with lesser abundant aster microscleres, a reduced number of sparsely spined rays, of irregular size, in general short and without micro-rotules at the extremities, small spicules, frequently attaining the condition of robust oxeas with some larger rays at the centre of the spicule, also devoid of micro-rotules at the extremities; megascleres stout, short, smooth megascleres, from straight to curved, abruptly pointed oxea, sometimes forming an angle in the medial portion; gemmoscleres short, uniform, sand-glass shaped amphidiscs with straight to slightly curved shafts, narrowed at the central portion and widened near the rotules, covered with small spines except near the rotules; these are umbonated, with thick irregularly indented profiles.

Description. Sponges cylindrical or bulbous, with smooth or lobated surfaces, encrusting the stems of aquatic vegetation, reaching a thickness of three centimeters; oscules of irregular sizes, randomly distributed over the surface (Fig. 38); skeleton reticulated anisotropic, main fibres thick, secondary fibres short thinner, organic bounding scarce; ectosome conspicuous, thin, consisting of an irregular tangential disposition of megascleres (Fig. 38) leaving only the oscular orifices free; gemmulles distributed from the base to the surface of the sponge though more concentrated

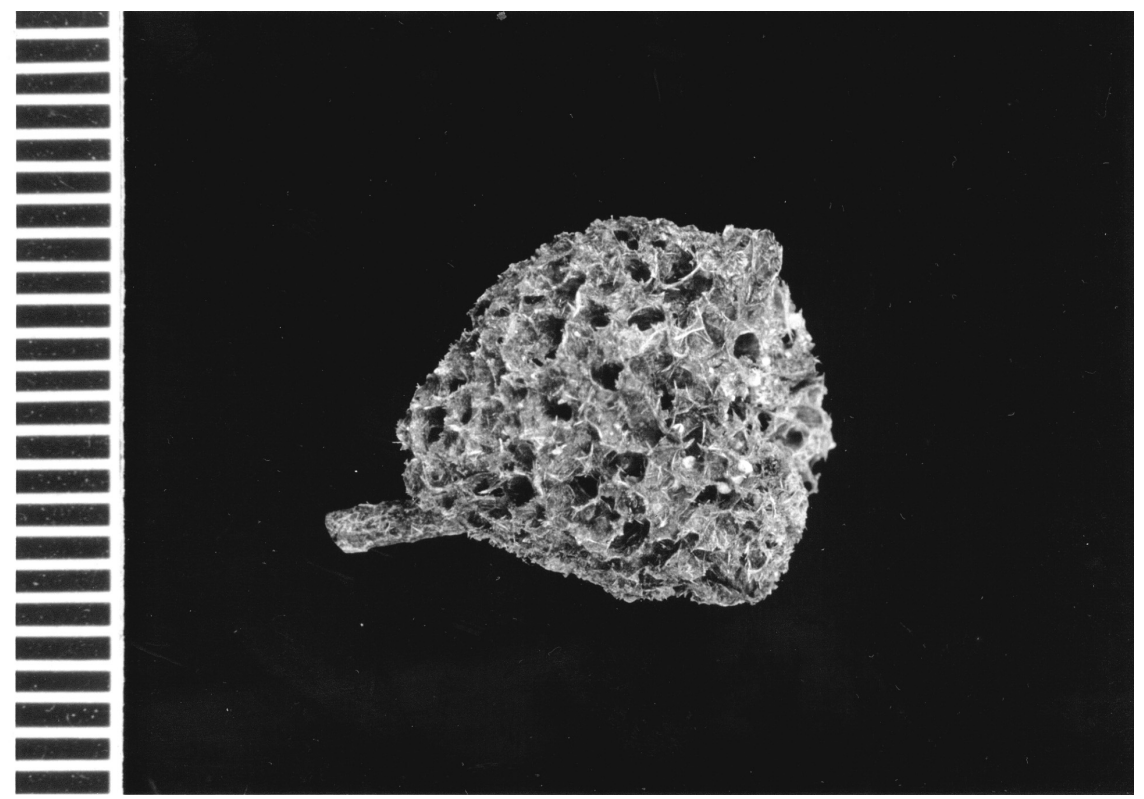

Figure 38. Dosilia brouni (Kirkpatrick, 1906), holotype BMNH 1905:6:30:6 (scale in millimetres). 
at the basal region; dry sponge yellowish, fragile and brittle.

Megascleres: straight or slightly curved, smooth, and abruptly pointed oxea; rare styles present as well as small oxeas simultaneously formed across a larger one.

Microscleres: asters consisting of 6 to 8 rays that originate from a widened central nodule; irregular ray lengths, generally short and sparsely microspined, the spines curved towards the central nodule; the reduction in the number of rays leads to thick microxeas with long, thick shafts, with several rays and large spines protruding from the original centrum or oxeas without rays and a larger number of short spines along the shaft; the extremities generally capped display an irregular arrangement of small spines curved towards the centre of the spicule; all the spines on the rays and shaft curved towards the central region of the spicules (Figs 39, 42-47).

Gemmoscleres: amphidiscs uniform, sand-glass shapped, rotules expanded, umbonate equal and with irregularly indented margins; gemmosclere shafts straigth and conspicuously enlarged towards the rotules; shaft spines small, regularly distributed but absent near the rotules (Figs 39, 48, 49, 52, 53); atypical gemmoscleres, though in small number, the shaft short, densely spined and rotules consisting of a tuft of short spines that project in all directions, or more rarely spicules practically without shafts consisting of tow opposite tufts of haphazardly projected spines (Figs 48, 49).

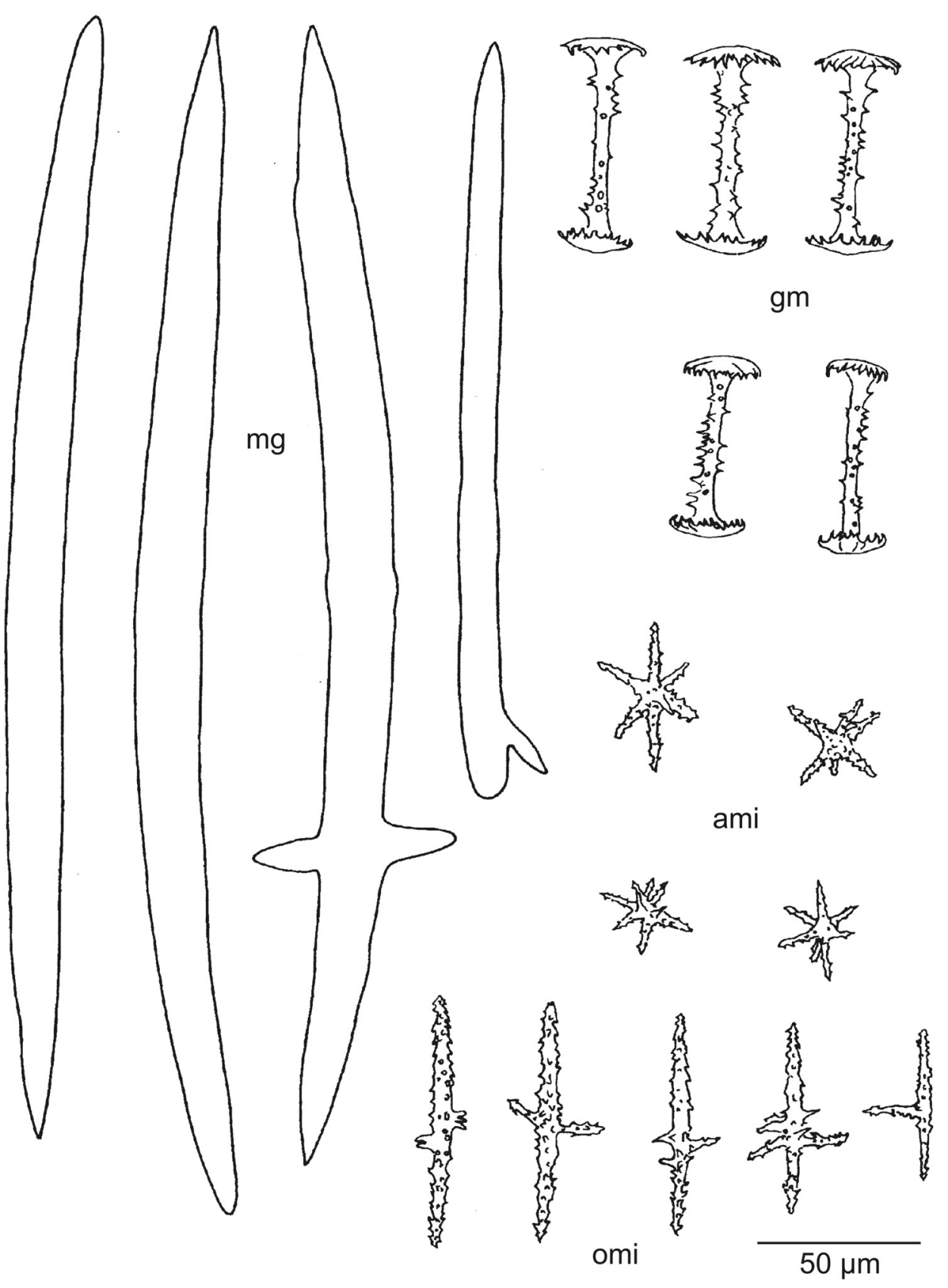

Figure 39. Dosilia brouni (Kirkpatrick, 1906), spicules: megascleres (mg); gemmoscleres (gm); astrose microscleres (ami); oxea microscleres (omi). 

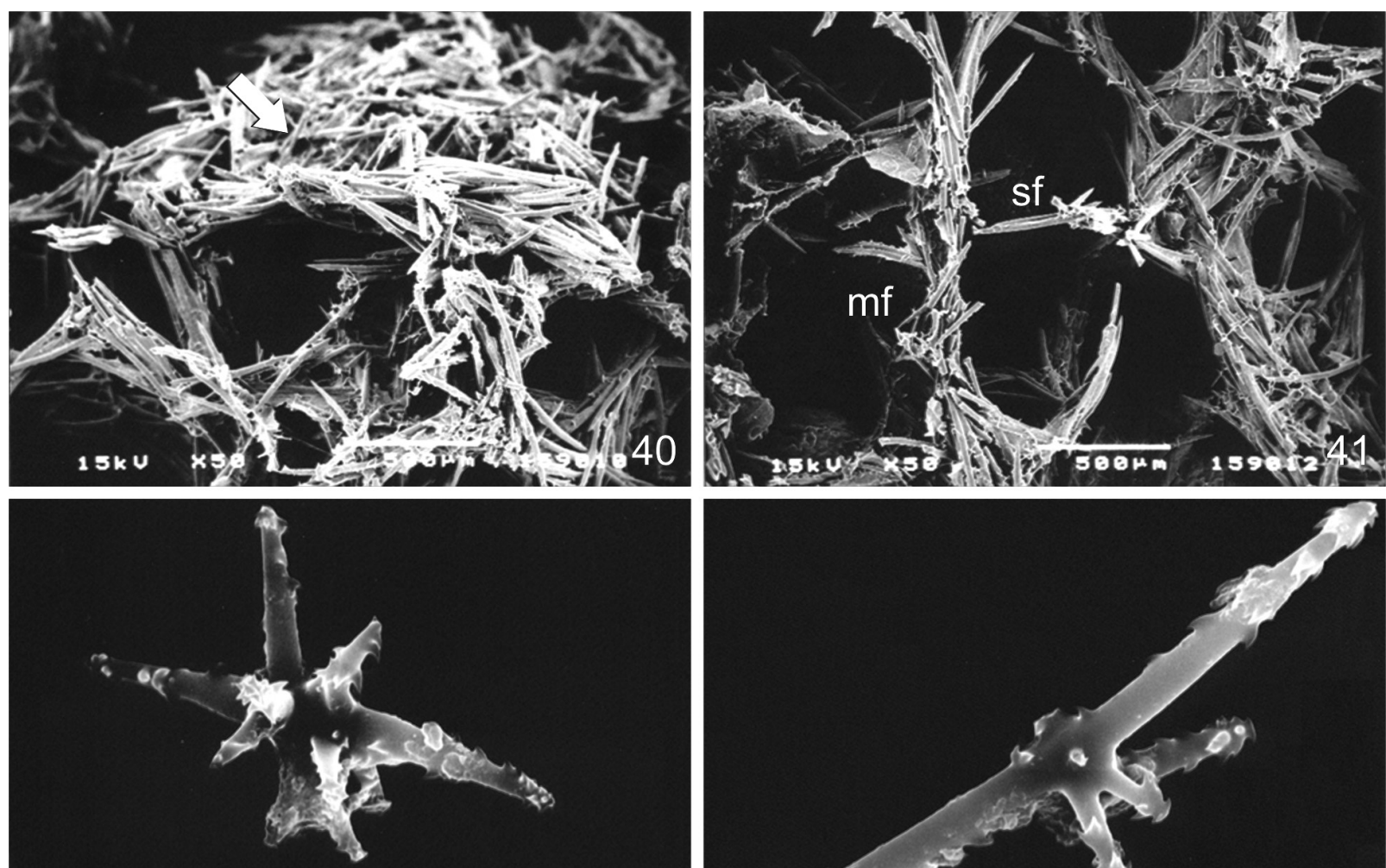

$25 k U \times 2,000$

$10 \mu \mathrm{m}$

42
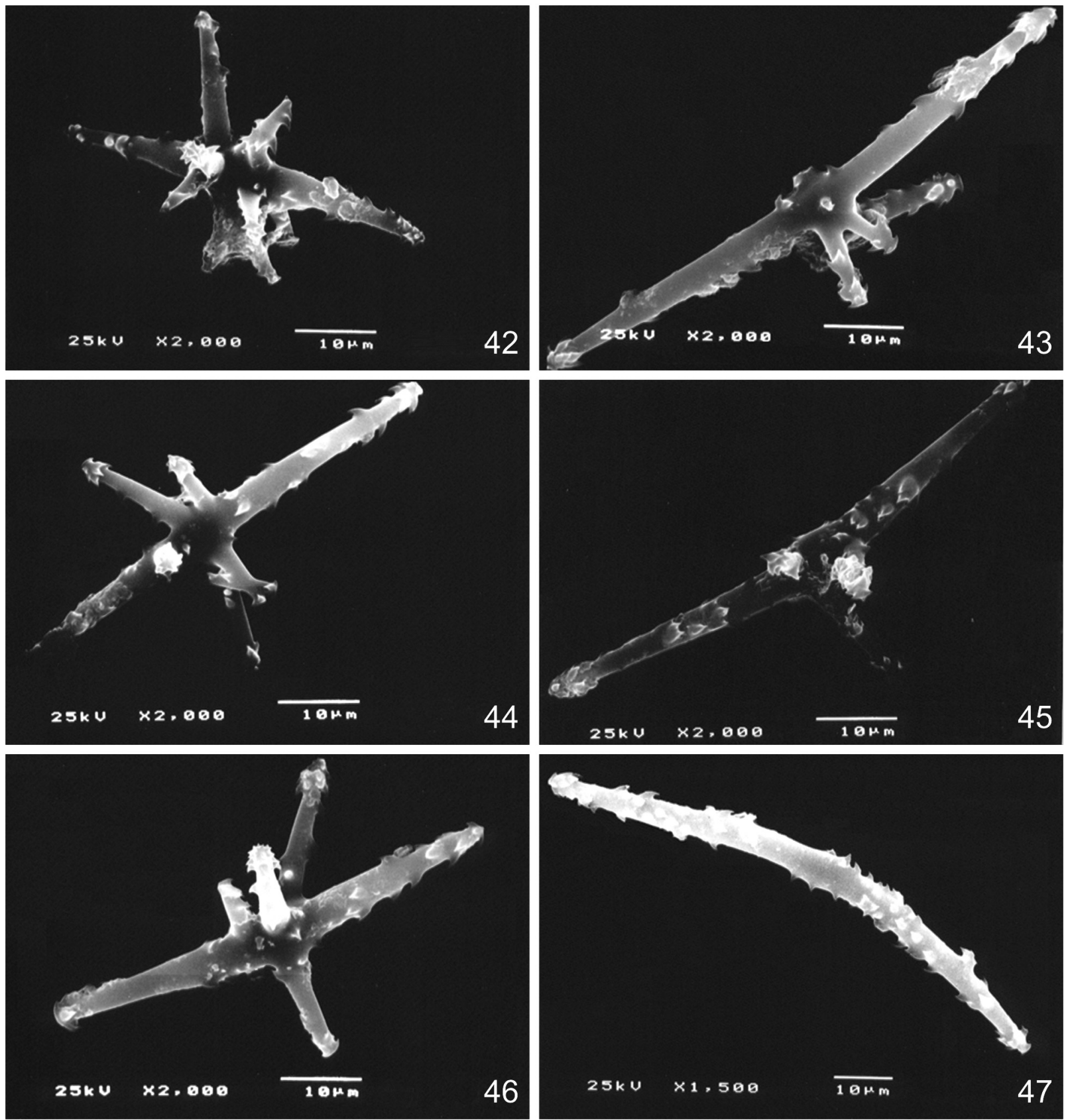

Figures 40-47. Dosilia brouni (Kirkpatrick, 1906): 40, ectosome with tangential arrangement of the megascleres: 41, main (mf) and secondary fibers (sf) of the reticulated skeleton; 41-47, gradual reduction of the rays in the astrose microsclere taking to the spined oxea microscleres, evidencing that the loss of rays is gained in lenght of the sclere. 

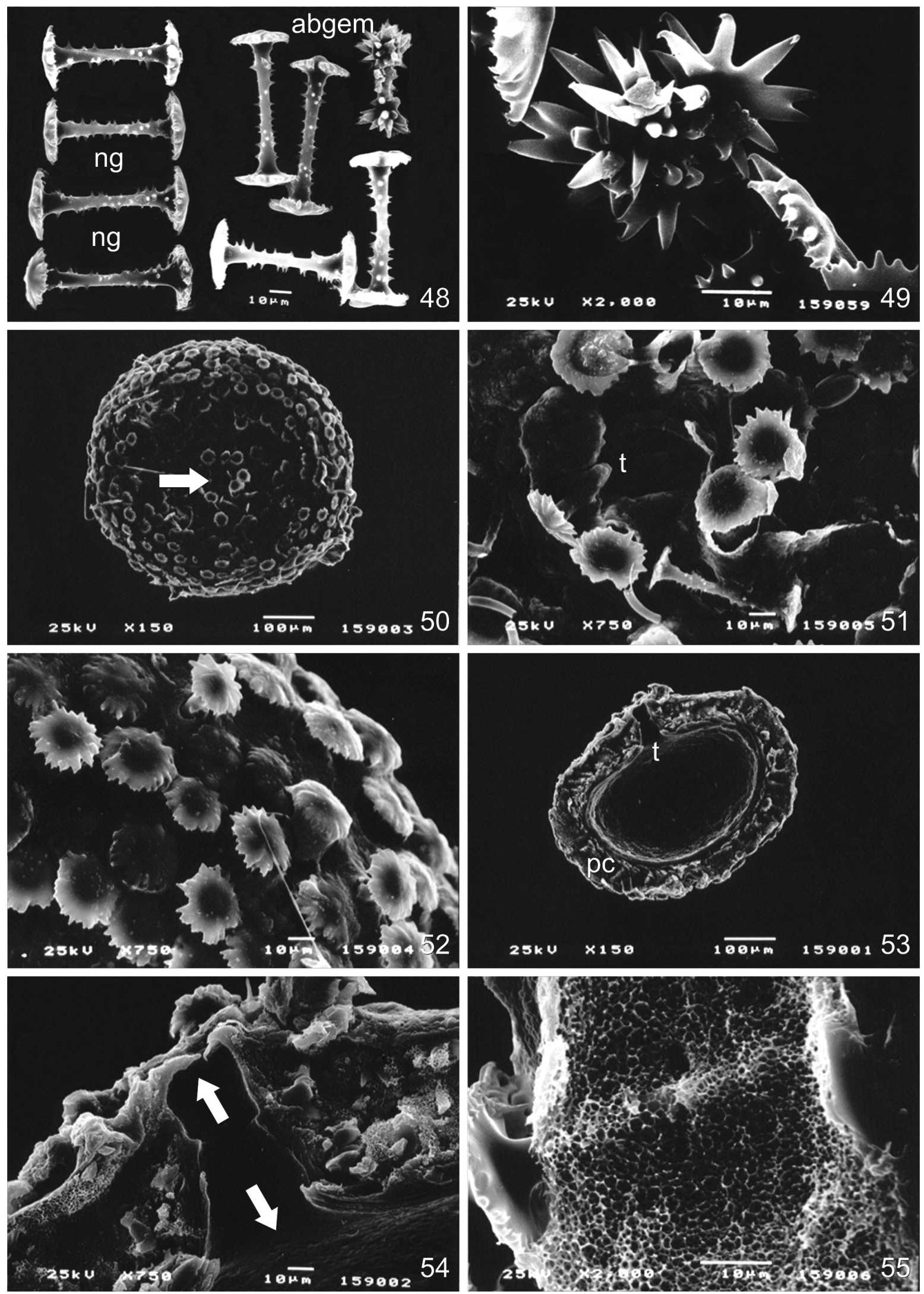

Figures 48-55. Dosilia brouni (Kirkpatrick, 1906): 48, uniform pattern of the gemmoscleres with their characteristic hour-glass shapped shafts. Normal gemmosclere (ng), abnormal gemmosclere (abgem); 49, atypical gemmosclere; 50, gemmule with foraminal tube (arrow); 51, magnification of the foraminal tube (t) area seen in fig. 50; 52, gemmule surface showing the rotules of the gemmoscleres projecting beyond the pneumatic coat; 53, cross section of the gemmule and the foraminal tube (t) showing also the thick pneumatic coat (pc); 54, detail of the foraminal tube with its bottom and upper sealing (arrows); 55, cross section of the thick pneumatic coat showing one embedded gemmoscleres and the small regular air spaces. 
Gemmulles: spherical or subspherical in shape, with pale coloration, a dense, well developed pneumatic layer over a laminated internal gemmular layer; radially disposed gemmoscleres with a rotule posed above the internal gemmular membrane and the axis embedded within the pneumatic layer; a rotule positioned at the external surface of the gemmule is, in general, covered by the external gemmular membrane; the foraminal tube, cylindrical and conical, with a wider base, crosses the pneumatic layer without projecting beyond it; two septa close the foraminal tube, one at the upper extremity and the other at the medial region (Figs 50-55).

Distribution. From the White Nile, 200 miles above Khartoum, Sudan, to Lake Baringo, Kenya.

Habitat. Banks of the White Nile subjected to seasonal flooding. The sponges encrust the seasonally flooded marginal vegetation (KIRKPATRICK, 1906). Similar habitat conditions are described for the specimens at Lake Baringo (WoRTHINGTON \& RicARdo, 1936; VACELET et al., 1991). A probable dispersion of the species from the White Nile to Lake Baringo along early and middle Holocene is suggested by VACELET et al. (1991). These authors report oligohaline waters of the Na-bicarbonate type for this shallow lake with short alternations between wet and dry periods and so dry and death periods for the vegetation and allied fauna at its marginal areas.

Remarks. KirkPATRICK (1906) describes the gemmosclere shafts of D. brouni as markedly curved and with axes considerably slender at the middle narrow in the central portion. PenNey \& RACEK (1968) disagreed with Kirkpatrick and describe the gemmoscleres shaft as being cylindrical, slightly curved and, occasionally, enlargened near the rotules. PENNEY \& RACEK (1968) claim to have analyzed syntype slides from the N. Gist Gee collection (USNM), which would characterize the existence of a series of collected samples. In the original description of D. brouni, KIRKPATRICK (1906) referred to only a single collected specimen, upon which the description was based. So the slides of Gee were from this sample, presently designated holotype by monotypy.

VACELET et al. (1991) describes the microscleres as acanthomicroxeas that may assume the aster aspect according to the length of the perpendicular rays present in the central region of the spicule. This way the just refered authors passed over with no discussion the original definition proposed by GRAY (1867) for the genus. However, the present comparative study of materials of the five known species of Dosilia shows that astrose microscleres are present in all of them as well as a more or less evident transition into microxeas.

The record of $D$. brouni for Venezuela, South America (Manconi \& Pronzato 2005), is evidently a wrong one and besides finds no support in the bibliography refered by those authors.

\section{Dosilia pydanieli Volkmer-Ribeiro, 1992 (Figs 56-66)}

Meyenia plumosa var. palmeri; TRAXLER, 1895:64, figs 22-25 (non Meyenia plumosa var. palmeri PotTs, 1885:587).

Dosilia pydanieli VolKMER-RIBEIRo, 1992:323; VolKMER-RIBEIRo \& MotTA 1995:145; VolKMER-Ribeiro et al., 1998a:410; VolKMERRibeiro et al., 1998b:271; VolKMER-RIBEIRO, 1999:3; CÂNDIDO et al., 2000:77.
Type material. Holotype, BRAZIL, Roraima: Alto Alegre (seasonal grassy pond at the Ecological Station of Maracá Island, Uraricoera river), (INPA-01, examined). Paratypes, same data of holotype, VII.22.1987 (MCN-POR 1379, examined); IV.12.1987 (MCN-POR 1509, examined), C. Volkmer-Ribeiro col. (localization and description: VOLKMER-RIBEIRO et al., 1998a).

Type locality: seasonal grassy pond at the Ecological Station of Ilha de Maracá, Uraricoera river, municipality of Alto Alegre, state of Roraima, Brazil (localization and description: VolKMER-Ribeiro et al., 1998a).

Material examined. BRAZIL, Roraima: Normandia (Caracaranã Lake), XII.16.1987, P. S. Mera col. (MCN-POR 1936); Rio Grande do Norte: Nísia Floresta (Lagoa Redonda), XI.17.1995, B. Canan col. (MCN-POR 3069); Maranhão: Santo Amaro (Lagoinha), X.30.1995, C. Volkmer-Ribeiro \& M. A Mendonça col. (MCN-POR 3857).

Diagnosis. Sponges with abundant, delicate, large, astrose microscleres, generally in the shape of a cross, with an inconspicuous centrum and long, thin, microspined, irregularly sized rays, capped by minute micro-rotules, the astrose microscleres displaying remarkable though rare variations up to the condition of spined oxeas, with a few to none rays in the central region or yet stout acanthostyles with a single ray originating from the previous centrum; megascleres long, thin, smooth, slightly curved oxea, with abruptly pointed extremities; gemmoscleres, uniform, long, thin amphidiscs, shafts straight, cylindrical, dense and irregularly covered by straight spines except in the proximity of the rotules, rotules expanded, from flattened to slightly umbonated, regularly incised into curved teeth.

Description. Living sponge brownish orange, charged with large whitish gemmulles and forming shallow, delicate crusts on seasonally submerged portions of aquatic plants; circular inconspicuous oscules; skeleton consisting at the base of the sponge of an anisotropic reticulum, very delicate and open, of fine fibres; the gemmular layer is formed within this basal part; a second skeletal layer is located over the basal layer, formed from thick horizontal fibres, long and mutually crossed that extend over the gemmular layer; thick pinacoderm, applied over the long horizontal fibres, or inconspicuous in the younger parts of the sponge (Figs 57-59).

Megascleres: long, thin, smooth, slightly curved oxeas, with abruptly pointed extremities, dilated areas may occur; rare styles may be present (Figs 56-59).

Microscleres: large aster forms, abundant, restricted to the ectosome, consisting of radially projected rays originating from a reduced central nodule also evolving through various forms of intermediate oxeas until reaching an stout acanthostyle with a single projected ray originating from the original centrum; extremities of the rays of the asters and oxeas provided with minute microrotules (Figs 56-60).

Gemmoscleres: amphidiscs thin with cylindrical shafts, densely and regularly spined, except near the rotules; shaft spines numerous, large, conical and sharp, some with micro-spined extremities; rotules of equal size 


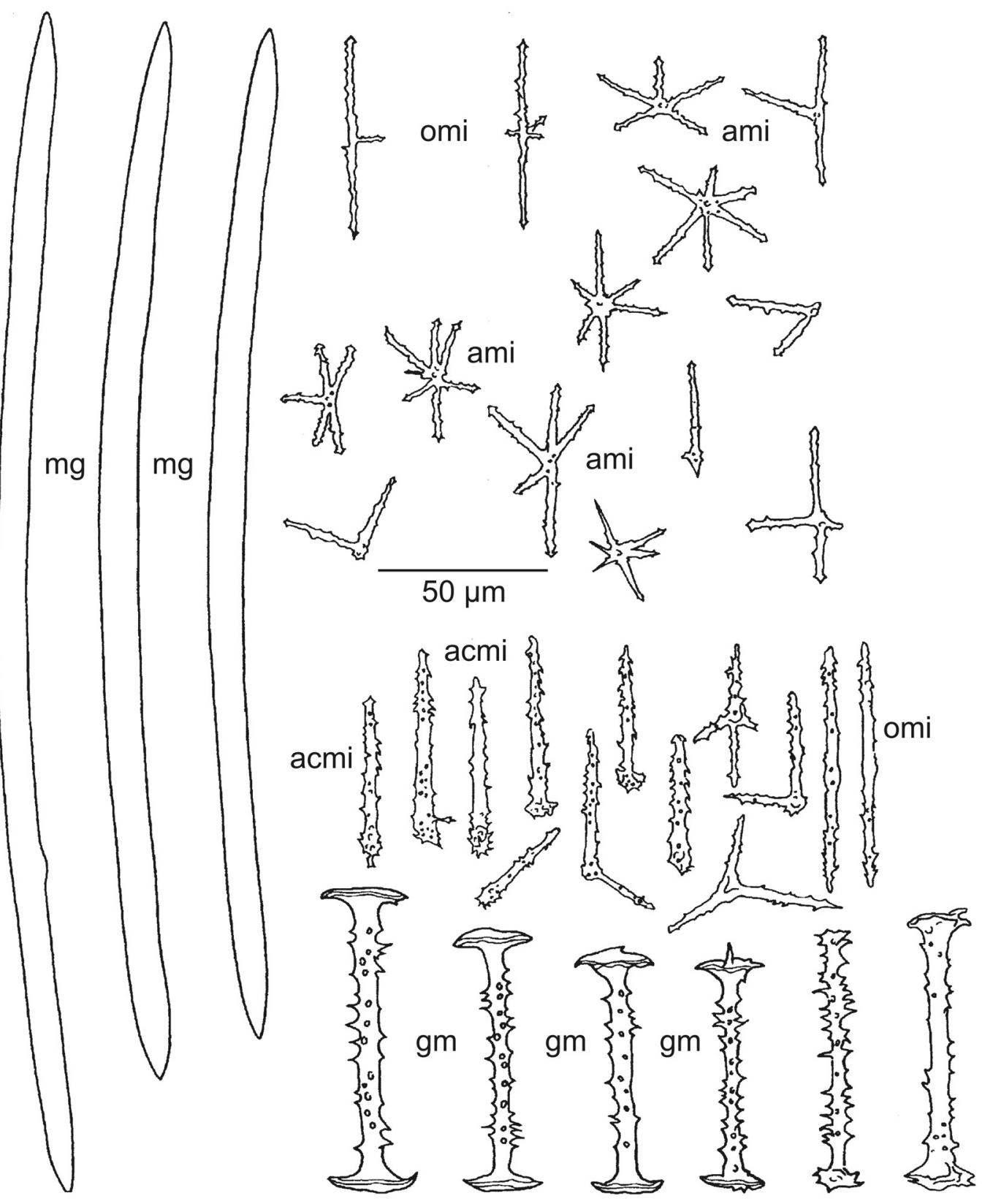

Figure 56. Dosilia pydanieli Volkmer-Ribeiro, 1992: megascleres (mg), gemmoscleres (g), astroses microscleres (ami), oxea microscleres (omi) and acanthotilostyles microscleres (acmi).

and shape, flattened to slightly umbonated, the thin edges regularly indented, the teeth turned towards the shaft (Figs 61, 62, 64-66).

Gemmulles: spherical or subspherical attached to the skeleton individually or in clusters; foraminal tube cylindrical, contained inside the pneumatic coat, straight and topped by an undulated collar; gemmoscleres radially embedded in the pneumatic coat, the outer rotule protruding from this coat; pneumatic coat thick, with minute air spaces; outer gemmular coat extending over the projection of the outer rotules (Figs 58, 63-66).

Distribution. South America, Brazil. From northern (state of Roraima) to northeastern (states of Maranhão and Rio Grande do Norte) to southeastern (state of São Paulo), Brazil, encompassing the Cerrado Biome and, as such, under tropical and subtropical climate.
Habitat. The sponge encrusts the submersed parts of the macrophytic vegetation at seasonal ponds or water tanks.

Remarks. The material studied by CÂNDIDO et al. (2000) permit the identification of a new variety of microscleres in this species, that may be, the stout acanthostyle, resulting from the reduction in the number of rays of the aster to the extreme of a ray originating from the original centrum.

\section{Dosilia Gray, 1867 redefined}

Dosilia Gray, 1867:550 (partim); Annandale, 1911a:110; 1911b:593; 1912:384; 1918:213; GeE, 1931:37; 1932:28; Laubenfels, 1936:37; Jewell, 1952:450; Penney, 1960:38; Penney \& RaceK, 1968:126; Boury-Esnault, 1980:209; Poirrier, 1982:59; VolKMer-Ribeiro \& TRAVESET, 1987:235; VACELET et al., 1991:11; 
Volkmer-Ribeiro, 1992:323; Manconi \& Pronzato, 2002:933; (non Dosilia Dybowsky, 1884.).

Spongilla CARTER, 1849:85 (partim); Bowerbank, 1863:449 (partim).

Meyenia CARTER, 1881:94 (partim); PotTs, 1887:233 (partim).

Heteromeyenia Mills, 1888:313 (partim); KIRKPATRICK, 1906:226. Asteromeyenia AnNANDALe, 1911b:593; GeE, 1931:32; LAUBEnFELS,

1936:36; Wurtz, 1950:5; Eshleman, 1950:42; JeWell, 1952:453;

PenNey, 1960:33.

Astroheteromeyenia SCHRÖDER, 1927:101.

Astromeyenia SCHRÖDER, 1927:101.

Type species: Spongilla plumosa Carter, 1849, subsequent designation by ANNANDALE (1911a).
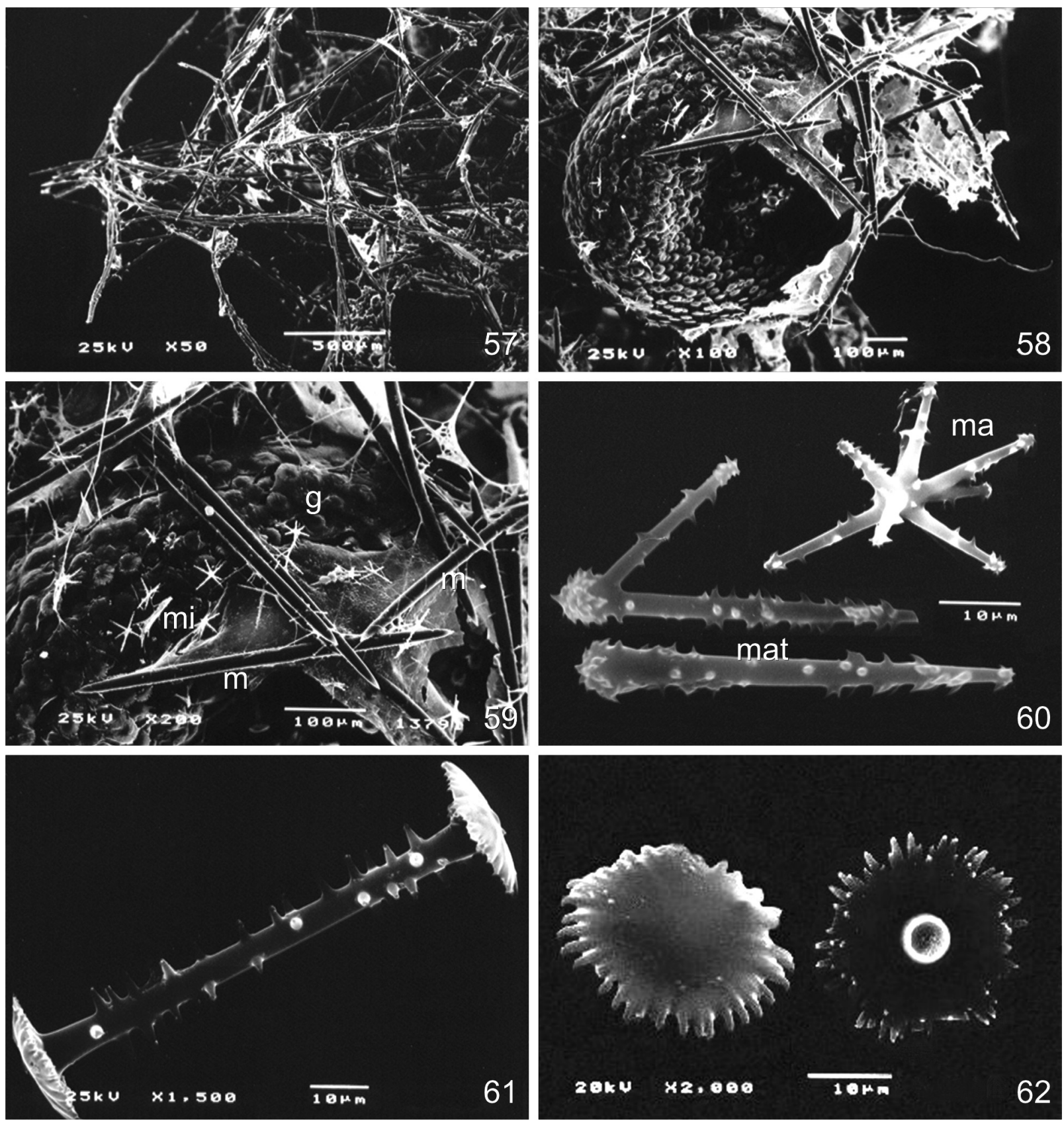

Figures 57-62. Dosilia pydanieli Volkmer-Ribeiro, 1992: 57, upper skeletal net with its main and secondary fibres; 58, sponge surface showing the pinacoderm, main thicker horizontal fibres and secondary unispicular fibres over one gemmule; 59, megascleres (m) of the main multispicular and the secondary unispicular fibres of the upper skeletal reticulum extended over one gemmule ( $\mathrm{g}$ ) and the pinacoderm encrusted with several astrose microscleres (mi); 60, variations of the number and shape of the rays in the astrose microscleres going from and aster (ma) to an acanthostyle (mat); 61, gemmosclere with the shaft regularly spaced conical spines and the almost flat rotule; 62, inner and outer surface of the rotules with the regular shallow cutting of the border and the reduced curvature of the border teeth. 

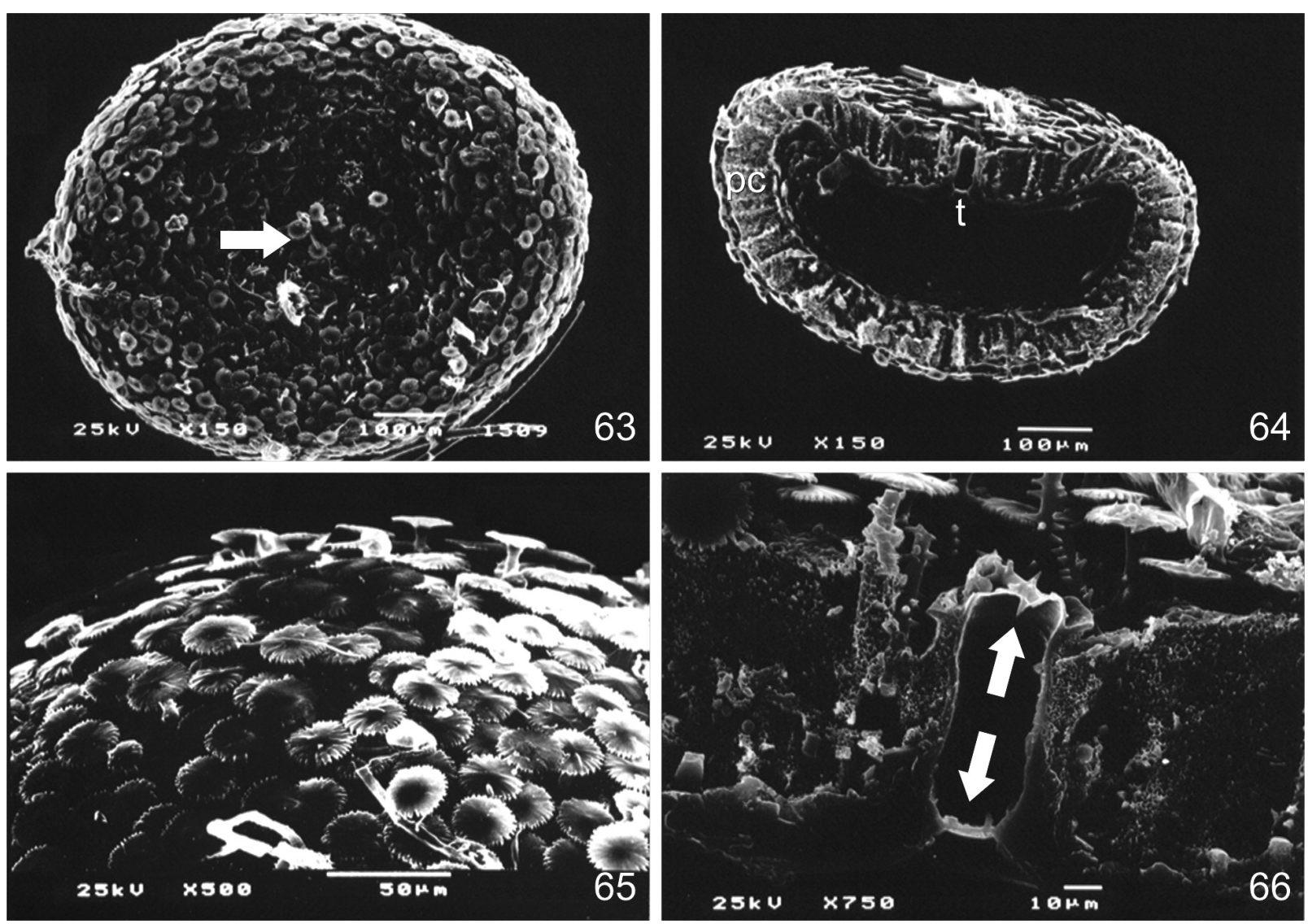

Figures 63-66. Dosilia pydanieli Volkmer-Ribeiro, 1992, gemmule: 63, surface with the foraminal tube at central position (arrow); 64, transverse section of gemmule showing the with foraminal tube (t) and the thick pneumatic coat (pc) with radial embedding of the gemmoscleres; 65, protruding rotules of the gemmoscleres with their smooth and flat profile; 66, detail of the cylindrical foraminal tube, showing its upper and bottom sealing (arrows) and the outer collar, the thick pneumatic layer, with regular small air cameras and the projection of the gemmular rotules beyond this layer.

flooded aquatic vegetation; anisotropic reticulated skeleton, almost devoid of organic bounding, generally having a radial disposition, primary fibres slender, secondary fibres short and extremely thin turning to mono-spicular; ectosome, when present, consists of a disordered tangential disposition of megascleres; three types of spicules: megascleres anfioxea, some rare styles present, cylindrical, straight or slightly curved, smooth or microspined, gradually to abruptly pointed; microscleres that vary in a same species and specimens form from asters, usually having approximately six rays of equal or irregular size, smooth or lightly spined, with or without microrotulation at the extremities, to fusiform microxeas, having or not having perpendicular rays or larger spines at the central region of the spicule and with sparse spines along the length of the axis; or sparsely spined acanthotylostyle microscleres, consisting of a large microrotulated ray that originates from a nodule; gemmoscleres amphidiscs of great variation in shape and size in a same species or devoid of variation, shafts spiny, cylindrical or enlargened towards the rotules, from long to short, from stout to slender, spines straight conical with prickly extremtities or microspined, inversely proportional in number to the length of the shaft and generally grouped in its middle part, rotules equal from strongly to lightly umbonated, deeply cut or indented, rays or teeth of rotules curved towards the shaft and split into three or four microspines.

Key to the species of Dosilia

1. Gemmoscleres quite uniform in shape as well as in size

Gemmoscleres with great variation of size and shape, the largest with conspicuously umbonate rotules formed by a few robust hooks (Figs 26, 28, 29), the smallest with expanded rotules their margins regularly cut in a number of incurved teeth (Figs 26,30) ........ Dosilia radiospiculata (Mills, 1888)

2. Shafts of gemmoscleres rod-like (Figs 6, 20,61) ....... 3 Shafts of gemmoscleres sand-glass like (Fig. 48) ...... Dosilia brouni (Kirkpatrick, 1906)

3. Megascleres smooth ...4

Megascleres conspicuously spined (Figs 15, 18) ..... ............................ Dosilia palmeri (Potts, 1885)

4. Astrose microscleres abundant, minute, with a conspicuous centrum and short stout microrotulated rays (Figs 3,4) ....... Dosilia plumosa (Carter, 1849)

Astrose microscleres large, delicate, with inconspicuous centrum and long, thin rays (Fig. 59) .......... Dosilia pydanieli Volkmer-Ribeiro, 1992 


\section{DISCUSSION}

Concern with the study of the type materials of the five species of Dosilia led to the verification that $D$. plumosa (Carter, 1849), D. radiospiculata (Mills, 1888) and D. brouni (Kirkpatrick, 1906) did not have, until the present study, type designation. Dosilia plumosa was designated type species for genus Dosilia by AnNANDALE (1911a) who, however, failed to designate a lectotype for the species. Dosilia radiospiculata, despite its importance within the genus, due to the wealth of spicules present in its structure, also remained without a designated type. Following Penney \& RACEK (1968), D. brouni was studied by VACELET et al. (1991), also without type designation. The original descriptions of $D$. brouni and $D$. radiospiculata were each based upon a single specimen, according to their respective authors. The description of D. plumosa was based upon three or four specimens collected by CARTER (1849) and today deposited in the BMNH. For these reasons, and based upon the analysis of the material made available by the BMNH and contained in specific bibliographies, holotypes were designated for $D$. radiospiculata and $D$. brouni and lectotypes and paralectotypes were selected for D. plumosa.

The analyses carried out using TLM and SEM allowed for the redescription of the five species of Dosilia, particularly D. plumosa and D. radiospiculata for which, until then, no SEM studies or illustrations were available. These studies showed a number of important generic and specific characteristics for the definition of the genus and the differentiation of the species and that, furthermore, refute the uniformity of the previous descriptions of the species.

The review study showed the following to be generic characteristics: (1) the occurrence of astrose microscleres, with smooth to sparsely spined rays in the five species of the genus, although each species exhibits particular variations in relation to the reduction of the number of microsclere rays; (2) the amphidisc gemmoscleres with equal rotules; (3) anisthotropic reticulated skeleton, of delicate, radial structure, consisting of primary and secondary fibres almost devoid of spongin while forming, occasionally, ectosome with a tangential arrangement of the fibres; (4) habitat, lentical environments in areas flooded by rivers, or reservoirs and temporary lakes, all having calm waters and a seasonal variation in the water level, occasioning periods of submersion and desiccation, generally in regions with tropical or subtropical climates, with few occurrences in areas of temperate climate.

In contrast to the uniform pattern of the descriptions of the species of Dosilia presented in PENNEY \& RACEK (1968), the SEM analysis confirmed specific variations that permitted the precise differentiation of the five species of the genus.

The astrose microscleres exhibited significant specific variations that until now were not highlighted. Dosilia plumosa with small abundant astrose forms, a large number of microrotulated rays, and the only species in which the astrose rays are rarely reduced to the condition of oxeas, in the other species this reduction is common. Dosilia radiospiculata also has abundant small astrose microscleres, but with a varied number of rays, occasionally microrotulated. Dosilia palmeri and $D$. brouni have fewer astrose forms, of varied size in the former and, generally small in the latter, with few rays deprived of micro-rotules. Dosilia pydanieli has abundant astrose microscleres, generally in a cross shape and, in contrast to the other species, always large, with a reduced number of rays, which are micro-rotulated. The reduction of the rays in the astrose microsclere, may attain in this species the condition of acanthostyle, which is unique in the genus (CÂNDIDo et al., 2000), enlarging the description of the species and contributing to the redefinition of Dosilia.

Dosilia radiospiculata, the most northern species, has the greatest degree of variation of the gemmoscleres, from very long, robust amphidiscs, with rotules in thick curved hooks, to short, less robust ones, with rotules little umbonated. Dosilia palmeri, less northern than $D$. radiospiculata, also exhibits some variation in the size of its gemmoscleres, though with less intensity. Dosilia plumosa, with subtropical and temperate distribution, exhibits gemmoscleres with little variation in the size and shape. Dosilia brouni and D. pydanieli, species that are restricted to tropical areas, in Africa and South America respectively, are poorer in terms of the degree of variation of their gemmoscleres. The former has a short, uniform gemmosclere, with shafts enlargening towards the umbonated rotules, while the latter has long delicate gemmoscleres, with cylindrical shafts and flattened rotules. Thus, it is possible to perceive a reduction or standardization of the characteristics of the spicules of Dosilia, the closer the species come to the Equator and the tropical climate. This tendency towards standardization is also seen in the megascleres, where $D$. palmeri and $D$. radiospiculata have long megascleres with relatively thick axes, from straight to slightly curved and micro-spined, except at the extremities that, in the former are abruptly pointed, while in the latter, they are gradually pointed. Dosilia plumosa, D. pydanieli and $D$. brouni have smooth megascleres with abruptly pointed extremities, yet the first two species, have long thin megascleres, while $D$. brouni has, characteristically, the shortest thickest megascleres of the genus, as well as having the most curved. In D. plumosa the megascleres are in general straight or slightly curved, while those of D. pydanieli are always slightly curved and extremely thin.

The gemmules in Dosilia are found free, dispersed throughout the sponge, with a tendency to greater concentration at the base of the skeleton and are characterized as presenting a single layer of gemmoscleres arranged radially over the internal gemmular membrane, laminated, over which is developed a dense pneumatic layer that envelops the gemmoscleres. The cylindrical to conical foraminal tube has two laminas or septa, one at the upper extremity and the other at the medial portion, close the tube. The gemmulles tend to be spherical to subspherical, with the exception of $D$. plumosa, in which they are characteristically ovoid.

The TLM and SEM analysis of the type material of Heteromeyenia plumosa Weltner, 1895 and $D$. 
radiospiculata show the equality of the spicular and skeletal characteristics, as well as the geographical distribution, determining the synonymisation of $H$. plumosa Weltner, 1895 with $D$. radiospiculata (Mills, 1888), definitively dismissing the proposal of nomen novum Dosilia heterogena Penney \& Racek, 1968 for $H$. plumosa Weltner, 1895.

The SEM analysis also led to the revelation of other unknown characteristics, such as the occurrence of microspines at the extremities of the teeth and hooks at the edges of the rotules of the gemmoscleres (Figs 7, 19, 31 ), as well as the presence, in the gemmoscleres in formation, of six orifices at the base of the indentation of the rotules, vestiges of the protein filaments of the gemmoscleres (Fig. 32) and also the occurrence of acanthostyle microscleres in D. pydanieli (Figs 56, 60), enlarging the description and confirming the specific status of the generic classification of Dosilia plumosa, D. palmeri, D. brouni and D. pydanieli as well as redefining the genus.

The genus Dosilia is, at present, constituted by five species, of which two are Nearctic, $D$. radiospiculata and D. palmeri; one Neotropical, D. pydanieli; one Ethiopic, D. brouni; and one Oriental, D. plumosa. The absence, up to the present, of registers of the genus for the Australian region, point to a geographic paragodwanic distribution of the genus instead of a discontinuous one, as proposed by PENNEY \& RACEK (1968). This verification leads to hypothesis either of extinction of Dosilia species in Australia or the existence of living specimens which may show up when more exhaustive surveys are carried out in this continent.

The occurrence of individuals of Dosilia in the floodplain areas of rivers (Ohio, Rio Grande and Colorado, Nearctic region; White and Blue Nile, Ethiopic region and Jhelum, Oriental region), in temporary lakes (north and northeast Brazil, Neotropical region) and in tanks and reservoirs (United States of America, Nearctic region; India, Oriental region), as well as the delicate and fragile structure of its skeletons, characterize the habitat of these sponges as being of lentic environments, calm waters, in general with an abundance of seasonal macrophytic vegetation and great seasonal variation in the level of the water, occasioning periods of submersion and desiccation.

Acknowledgments. The senior author acknowledges CNPq for the fellowship granted in the Graduate Program of Zoology of Pontifícia Universidade Católica do Rio Grande do Sul (PUCRS) when this revisional work was carried out as part of a M.Sc. dissertation. C. Volkmer-Ribeiro acknowledges the following curators/researchers for the loaning of type materials: Miss Shirley Stone and Miss Clare Valentine (BMNH), Prof. Jean Vacelet (Centre d'Oceanologie de Marseille, Station Marine d'Endoume, Marseille), Dr. Peter Bartsh (ZMB), and Dr. Stephen Cairns (USNM). Miss Rejane Rosa and Augusto Seidel (Museu de Ciências Naturais, Fundação Zoobotânica do Rio Grande do Sul, Porto Alegre, RS), for respectively, the final art of the drawings and the digital edition of all the plates. Permission was granted to the authors by the BMNH, for reproduction of the photographs of the lectotype of Dosilia plumosa and holotype of Dosilia brouni (Figs 1 and 38). To Prof. Inés Ezcurra de Drago (Instituto Nacional de Limnologia, Santa Fé, Argentina) and Prof. Sheila M. Pauls (Facultad de Ciencias, Universidade Central de Venezuela, Caracas, Venezuela) for review and valuable suggestions offered to this paper. To M.Sc. Glayson A. Bencke of the editorial commission for help with the edition of Figures 1 and 38. To $\mathrm{CNPq}$, for the research fellowship and corresponding grant to $\mathrm{C}$. Volkmer-Ribeiro.

\section{REFERENCES}

AnNandale, N. 1909. Freshwater sponges in the collection of the United States National Museum - Part II. Specimens from North and South America. Proceedings of United States National Museum 37:401-406.

Annandale, N. 1911a. Freshwater sponges, hydroids and Polyzoa. In: Annandale, N. ed. The fauna of British India, including Ceylon and Burma. London, Taylor and Francis. p.27$126,241-245$

1911b. Freshwater sponges in the collection of the United States National Museum - Part V. A new genus proposed, with Heteromeyenia radiospiculata Mills as type. Proceedings of United States National Museum 40:593-594.

1912. The freshwater sponges of the Malabar zone. Records of the Indian Museum 7:383-397.

1914. Spongillidae. In: Michaelsen, W. ed. Beiträge zur Kenntnis der Land- und Süsswasserfauna DeutschSüdwestafrikas. Hamburg, L. Friederichsen. p.236-249.

1918. Zoological results of a tour in Far East. II. Freshwater Sponges from Japan, China, and the Malay Peninsula. Memoirs of the Asiatic Society of Bengal 6:199-216.

ARndT, W. 1933. Zur Kenntnis der Süsswasserschwammfauna Mexikos. Fragmenta Faunistica. Musei Zoologici Polonici Tom II 8(5):17-26.

1936. Die von Dr. A. Monard in Angola gesammelten Süsswasserschwämme, mit einem Überblick über die Spongillidenfauna Afrikas nach dem gegenwärtigen Stand unserer Kenntnisse. Arquivos do Museu Bocage 7:7-35.

Boury-Esnault, N. 1980. Spongiaires. Flore et Faune aquatiques de l'Afrique sahelosoudanienne. ORSTOM 44:199-217.

Bowerbank, J. S. 1863. A monograph of the Spongillidae. Proceedings of Zoology Society of London 1863:440472 .

CÂndido, J. L.; Volkmer-Ribeiro, C.; Simões Filho, F. F. L.; TurQ, B. J.; Desjardin, T. \& Chauvel, A. 2000. Microsclere variations of Dosilia pydanieli (Porifera: Spongillidae) in Caracaranã lake (Roraima - Brazil). Palaeoenvironmental implication. Biociências 8(2):77-92.

CARTER, H. J. 1849. A descriptive account of the freshwater sponges (genus Spongilla) in the island of Bombay, with observations on their structure and development. The Annals and Magazine of Natural History 4:81-100.

1881. History and classification of the known species of Spongilla. The Annals and Magazine of Natural History 7:77-107.

Dyвошsкy, W. 1884. Ein Beitrag zur Kenntnis des Süswasserschwammes Dosilia stepanowii. Zoologischer Auzeiger 7(176):476-480.

Eshleman, S. K. 1950. A key to Florida's freshwater sponges with descriptive notes. Quarterly Journal of Florida Academy of Sciences 12:35-44.

Frost, T. M. 1991. Porifera. In: Thorp, J. H. \& CoRvich, A. eds. Ecology and Classification of North American Freshwater Invertebrates. San Diego, Academic. p.95-124.

GeE, N. G. 1931. A contribution towards an alphabetical list of the known freshwater sponges. Peking Natural History Bulletin 5(1):31-52

1932a. The known freshwater sponges. Peking Natural History Bulletin 6(3):25-51

1932b. Another collection of freshwater sponges from the Phillipine Islands. The Phillipine Journal of Science 49(4):505-541.

GrAY, J. E. 1867. Notes on the arrangement of sponges, with the description of some new genera. Proceedings of the Zoological Society of London 1:492-558.

Harrison, W. F. 1974. Sponge (Porifera: Spongillidae). In: Hart, C. W. \& Fuller, S. L. H. Pollution Ecology of Freshwater Invertebrates. New York, Academic. p.29-66.

Jewell, M. E. 1952. The genera of north american freshwater sponges; Parameyenia, new genus. Transaction of Kansas Academy of Science 55:445-457.

KeLlicott, D. S. 1891. The Mills collection of freshwater sponges. Bulletin Buffalo Society Natural Science 5:99-104. 1897. Preliminary report on the freshwater sponges of Ohio. $5^{\text {th }}$ Annual Report of the Ohio State Academy of Sciences 1-50. 
Kirkpatrick, R. 1906. Report on the Porifera, with notes on species from Nile and Zambesi. Zoological results of the third Tanganyika Expedition. Proceedings of the Zoological Society of London 1:218-227.

Laubenfels, M. W. 1936. A discussion of the sponge fauna of the Dry Tortugas in particular and the West Indies in general, with material for a revision of the families and orders of the Porifera. In: Carnegie Institute Work Publications ed. Papers tortugas Lab. Washington, Carnegie Institute Work Publications. v.30, 1-225p.

Manconi, R. \& Pronzato, R. 2002. Suborder Spongillina subord. nov.: Freshwater sponges. In: Hooper, J. N. A. \& Van Soest, R. W. M. eds. Systema Porifera: A Guide to the Classification of Sponges. New York, Kluwer Academic/ Plenum. p.921-1019.

2005. Freshwater sponges of the West Indies: discovery of Spongillidae (Haplosclerida, Spongillina) from Cuba with biogeographic notes and a checklist for the Caribbean area. Journal of Natural History 39(36):3235-3253.

2009. Atlas of African freshwater sponges: Studies in Afrotropical Zoology. Tervuren, Royal Museum for Central Africa. 214p.

Mills, H. 1884. Thoughts on the Spongidae, with reference to the American sponges of the freshwater group with some accounts of them in detail. Proceedings of the American Microscope 131-147.

1888. A new freshwater sponge, Heteromeyenia radiospiculata n. sp. Annals and Magazine of Natural History 1(6): 13-314.

Old, M. C. 1936. Additional North American freshwater sponge records. Transactions of the American Microscopical Society 55:11-13.

Penney, J. T. 1960. Distribution and bibliography (1892-1957) of freshwater sponges. University of South Carolina Publisher III 3(1):1-97.

Penney, J. T. \& RaceK, A. A. 1968. Comprehensive revision of a worldwide collection of freshwater sponges (Porifera: Spongillidae). Bulletin of the United States Natural Museum Smithsonian Institution 272:1-184.

Poirrier, M. A. 1972a. Studies on southern Sisyridae (Spongillaflies) with a key to the third-instar larvae and additional sponge-host records. The American Midland Naturalist 88(2): $455-458$.

1972b. Additional records of Texas fresh-water sponges (Spongillidae) with the first record of Radiospongilla cerebellata (Bowerbank, 1863) from the western hemisphere. Southwestern Naturalist 16:434,435.

. 1982. Porifera. In: Hurlbert, S. H. \& Villa Lobos-Figueroa, A. eds. Aquatic Biota of Mexico, Central America and the West Indies. San Diego, San Diego State University, p.59-61.

Potтs, E. 1881. Some new genera of freshwater sponges. Proceedings of Academy of Natural Sciences of Philadelphia 1881:149-150.

1885. Freshwater sponges from Mexico. Proceedings of the United States National Museum 8:587-589.

1887. Contributions towards a synopsis of the American forms of freshwater sponges with descriptions of those named by others authors and from all parts of the world. Proceedings of Academy of Natural Sciences of Philadelphia 1887: $157-279$.

RiojA, E. 1940. Estudios hidrobiológicos I. Estudio critico sobre las esponjas del lago de Xochimilco. Anales del Instituto de Biologia de Mexico 11(2):173-189.

1953. Estudios hidrobiológicos XI. Contribución al estudio de las esponjas de agua dulce de Mexico. Anales del Instituto de Biologia de Mexico 24:425-433.
Schröder, K. 1927. Über die gattungen Carterius Pert, Astromeyenia Annandale und Heteromeyenia Potts (Porifera: Spongillidae). Spongilliden Studien III. Zoologischer Anzeiger 73:101-112.

SмIтH, F. 1921. Distribution of the freshwater sponges of North America. Department of Registration and Education, Natural History Survey Division 14:10-22.

SowkA, P. A. 1999. Occurrence of two species of freshwater sponges (Dosilia radiospiculata and Ephydatia muelleri) in Arizona.The Southwestern Naturalist 44(2):211-212.

TRAXLER, L. 1895. Spikule von Sübwasserschwämmen aus Brasilien. Földani Kölzlöny 25:62-64.

Vacelet, J.; Tiecerlin, J. J. \& Gasse, F. 1991. The sponge Dosilia brouni (Spongillidae) in Lake Baringo, Gregory Rift, Kenya. Hydrobiologia 211:11-18.

VOLKMER-Ribeiro, C. 1992. The freshwater sponges in some peatbog ponds in Brazil. Amazoniana 12(2):317-335. 1999. Esponjas. In: Joly, C. A. \& Bicudo, C. E. Biodiversidade do Estado de São Paulo; síntese do conhecimento ao final do século XX, 4: Invertebrados de água doce. São Paulo, FAPESP. p.1-9.

2007. South American Continental sponges: state of the art of the research. In: Custodio, M. R.; LôBo-Hadju, G. \& Muricy, G. eds. Porifera research: biodiversity, innovation and sustainability. Rio de Janeiro, Museu Nacional. p.117-121.

VolKmer-Ribeiro, C. \& MotTA, J. F. M. 1995. Esponjas formadoras de espongilitos em lagoas no Triângulo Mineiro e adjacências, com indicação de preservação de hábitat. Biociências 3(2): 145-169.

Volkmer-Ribeiro, C. \& Rützler, K. 1997. Pachyrotula, a new genus of freshwater sponges from New Caledonia (Porifera: Spongillidae). Proceedings of the Biological Society of Washington 110(4):489-501.

Volkmer-Ribeiro, C. \& Traveset, A. 1987. Annotated Catalog of the Type Specimens of Pott's Species of Freshwater Sponges. Proceedings of the Academy of Natural Sciences of Philadelphia 139:223-242.

VolKmer-Ribeiro, C. \& TurCQ, B. 1996. SEM analysis of siliceous spicules of a freshwater sponge indicates paleoenvironmental changes. Acta Microscopica 5(B):186,187.

Volkmer-Ribeiro, C.; Mansur, M. C.; Mera, P. S. \& Ross, S. M. 1998a. Biological indicators of the quality of water on the island of Maracá, Roraima, Brazil. In: Miliken, W. \& Ratter, J. A. eds. MARACÁ: The biodiversity and environment of an Amazonian Rainforest. London, John Wiley \& Sons. p. 403-414.

Volkmer-Ribeiro, C.; Motta, J. F. M. \& Callegaro, V. L. M. 1998 b. Taxonomy and Distribution of Brazilian Spongillites. In: Watanabe, Y. \& Fusetani, N. eds. Sponge Sciences, Multidisciplinary Perspectives. Tokio, Springer-Verlag. p. 271-278.

WeLtner, W. 1895. Spongillidenstudien III. Katalog und Veibreitung der bekannten Süsswasserschwämme. Archiv für Naturgeschichte 61(1):114-144.

1913. Süsswasserschwämme (Spongillidae) der Deustchen Zentralafrika Expedition 1907-1908. Ergebnisse Deutschen Zentralafrika Expedition. Zoology 4:475-485

Worthington, E. B. \& Ricardo, C. K. 1936. Scientific results of the Cambridge Expedition to the East African Lakes 1930-1: The fishes of Lake Rudolf and Lake Baringo. Journal of Limnology Society 39:353-389.

Wurtz, C. B. 1950. Freshwater sponges of Pennsylvania and adjacent states. Notulae Natura 228:1-10.

Zubair, S. M.; Singh, R.; Jyoti, M. K \& Sharma, K. K. 2006. Dosilia plumosa: a new record from Jamu, J \& K. Aquacult 7(2):237-44.

Recebido em outubro de 2010. Aceito em dezembro de 2010. ISSN 0073-4721

Artigo disponível em: www.scielo.br/isz

Impresso e distribuído em 2011. 